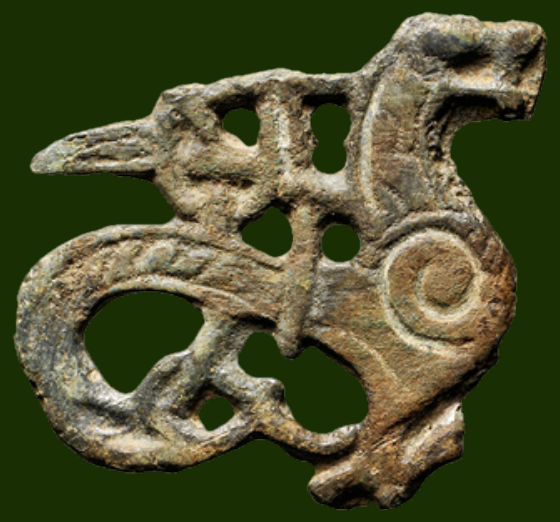

KUML

2016 


\section{KUML 2016}

Årbog for Jysk Arkæologisk Selskab

With summaries in English

I kommission hos Aarhus Universitetsforlag 


\section{Tamdrup \\ Kongsgård og mindekirke i nyt lys}

Tamdrup er omgærdet af en vis mystik. Den ensomt beliggende kirke på morænebakken vest for Horsens kan ses langvejs fra og har i århundreder tiltrukket sig opmærksomhed. Umiddelbart ligner den en ordinær sognekirke, men ved nærmere øjesyn er den ualmindelig stor, og træder man indenfor, viser det sig, at der samlet under ét tag gemmer sig en treskibet konstruktion, der oprindeligt var en romansk basilika. Hvorfor har man opført så stor en kirke på netop dette sted? Hvilke omstændigheder gjorde sig gældende i den tidlige middelalder, da grundstenen blev lagt?

Kirken ligger centralt i Tamdrup sogn, der således har navn efter et sted, der i dag kun findes i forbindelse med kirken samt den nærliggende Tamdrup Bisgård. I vikingetid og tidlig middelalder har navnet imidlertid også været knyttet til en bebyggelse og en plads, som traditionelt opfattes som en stormands- eller kongsgård, og som denne artikel nærmere vil søge at definere og forklare.

Gåden om Tamdrup er tidligere blevet belyst og diskuteret. I 1980'erne og 1990'erne blev der foretaget arkæologiske udgravninger, der viste spor af en stormandsgård fra sen vikingetid og tidlig middelalder. ${ }^{1} \mathrm{Nu}$ er der via metaldetektorfund kommet nye oplysninger til. De nye fund bidrager med flere svar, men giver også anledning til nye spørgsmål og problemstillinger.

Tolkningen af Tamdrup Kirke og dens betydning har været omdiskuteret siden 1800-tallet, hvor den kom på det danmarkshistoriske kort på grund af dens særlige form og størrelse. ${ }^{2}$ Trods senmiddelalderlige om- og tilbygninger i gotisk stil med korforlængelse, indsætning af hvælv og tilføjelse af våbenhus og tårn er det tydeligt, at kirken oprindeligt var en treskibet romansk basilika med fladt træloft og apsider på både kor og sideskibe. Over hvælvene i skib og kor er de oprindelige, tidligt romanske kalkmalerier bevaret, og i korbuen ses de samtidige afbildninger af Kristus flankeret af Kain og Abel i stil med kalkmalerierne i Jelling. Døbefonten er usædvanlig flot og viser bl.a. de fire evangelistsymboler i højt relief i stedet for de sædvanlige løver på de jyske 


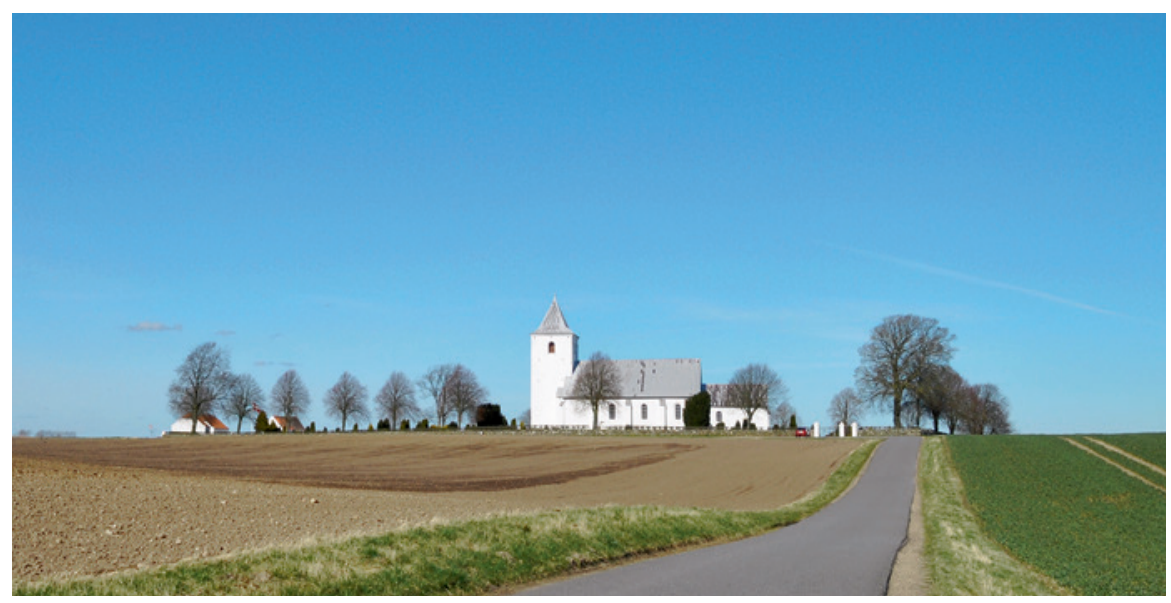

Fig. 1. Tamdrup Kirke i landskabet set fra syd. - Foto: Lars Pagh.

Tamdrup church seen from the south.

fonte. Det gyldne alter, der står i kirken i dag, er beklædt med kopier af de originale forgyldte kobberplader, der befinder sig i Nationalmuseet og dateres til omkring år 1200.

Opførelsen af Tamdrup Kirke er dateret til 1125 ved hjælp af dendrokronologisk datering af vinduesrammer fra romanske vinduer. I bogværket Danmarks Kirker opfattes kirken som en tidlig dåbskirke. Syv af pladerne i det gyldne alter viser Poppo-legenden, hvor Poppo omvender kong Harald Blåtand ved at bære glødende jern, og selvom de i dag er placeret på det gyldne alter sammen med de øvrige, bibelske motiver, er det ikke utænkeligt, at de stammer fra et relikvieskrin til den hellige Poppo. Tamdrup er det eneste sted i Danmark, hvor Poppo-legenden, der er helt central for kristningen af Danmark, påviseligt er blevet dyrket. At Poppo bar glødende jern er beskrevet af den tyske historieskriver Widukind, der levede samtidig med Poppo og Harald Blåtand. ${ }^{3}$ Også den danske krønikeskriver Saxo beretter om Poppo. Saxo blev født omkring 1160 og skrev på ærkebiskop Absalons opdrag sit store værk Gesta Danorum (Danernes bedrifter) omkring 1200. Saxo holder sig ikke til Widukinds historieskrivning, men gør Sven Tveskæg til den konge, der omvendes af Poppo. ${ }^{4}$ Formentlig skal man holde sig til Widukinds oprindelige udlægning og være varsom med Saxo, men han er interessant i forhold til de gyldne plader med Poppo-legenden, der tilsyneladende er udført på Saxos tid. På en af pladerne bærer Poppo en jernhandske (fig. 3). Hos Widukind er der ikke nævnt en handske, men det er der i Saxos version. Pladerne er fremstillet til Tamdrup Kirke, der formentlig er opført til minde om kristningen af Danmark, belig- 
gende i Aarhus stift, hvor Poppo ifølge Saxo efter omvendelsen af den danske konge blev gjort til biskop, udnævnt af ærkebispen af Hamborg-Bremen, der også optræder på pladerne.

Arkæologiske undersøgelser har påvist kristne begravelser, der er ældre end stenkirken, og det antages derfor, at der må have været en forgænger i træ, der kan have været en egentlig dåbskirke. ${ }^{5}$ Denne teori understøttes af, at kirken efter de tidlige kalkmalerier at dømme har dyrket Johannes Døberen, og at kirken derfor kan have været viet til både Johannes Døberen og Sankt Poppo. Som nævnt er det endvidere sandsynligt, at kirken har været valfartskirke, hvor man har dyrket relikvier af Poppo, opbevaret i et skrin med de forgyldte plader med Poppo-legenden. En sådan eksklusiv kult passer med, at Tamdrup har været mindekirke for landets kristning, og den er vanskelig at forestille sig uden en tradition for, at jernbyrd og kongedåb skulle være foregået netop i Tamdrup. ${ }^{6}$

Tamdrup Kirke må være opført under kong Niels, men måske allerede planlagt under Erik Ejegod omkring år 1100. En monumental kirke, opført som manifestation og legitimering af kongemagten.

Selvom de skriftlige kilder er tavse, er indicierne så stærke, at tolkningen virker meget overbevisende. Men mens kilderne tier om kongens Tamdrup, er de mere oplysende, når det gælder det senere tilhørsforhold til Aarhusbispen. Syd for kirken ligger Tamdrup Bisgård. Som navnet antyder, har gården

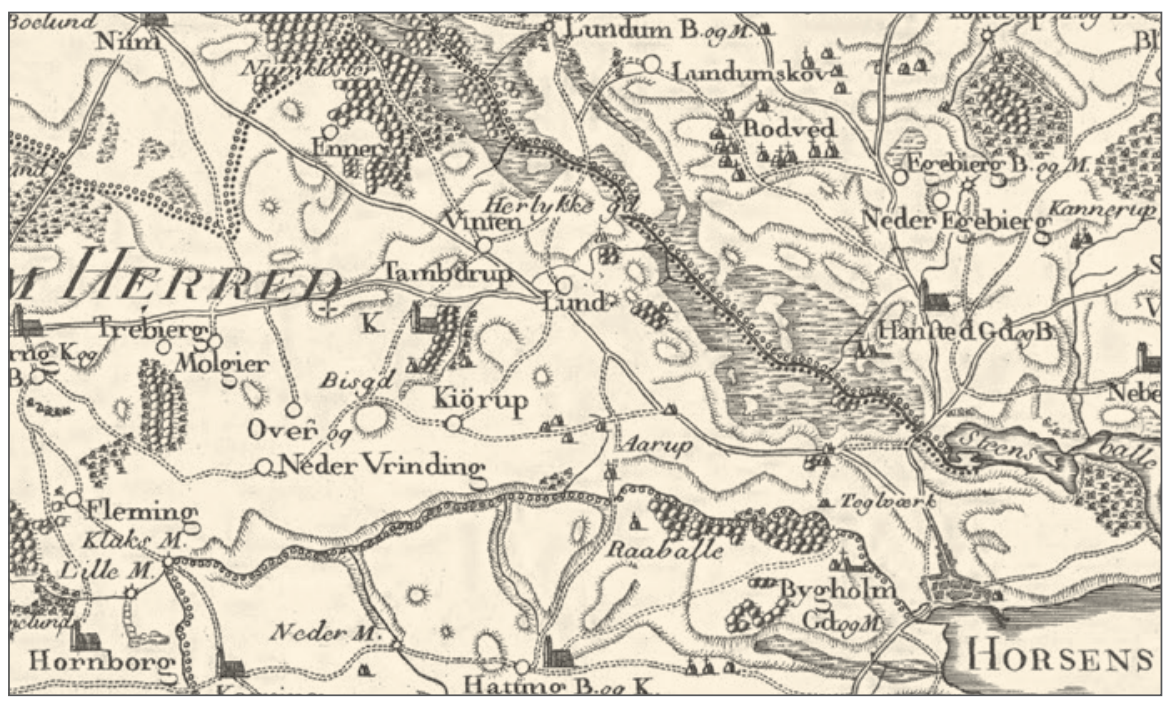

Fig. 2. Tamdrup på Videnskabernes Selskabs Kort 1787.

Tamdrup on the Danish Royal Society map of 1787. 
Fig. 3. Gylden plade fra Tamdrup Kirke. Poppo bærer jernbyrd - i Saxos version - med handske.

- Foto: Nationalmuseet.

Gold relief from Tamdrup church. Poppo's ordeal by fire - Saxo's version - wearing a glove.

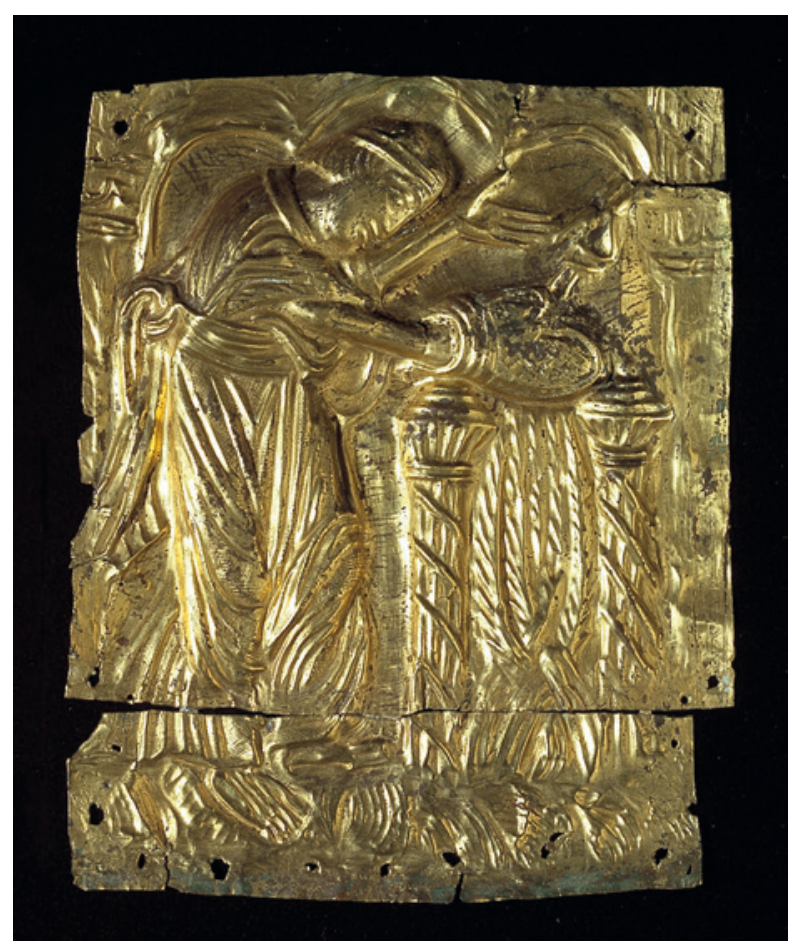

en periode været bispens ejendom. Tamdrup findes ikke i fortegnelsen over kongens ejendom i kong Valdemars jordebog fra 1231, men optræder for første gang i en skriftlig kilde i 1279, hvor bisp Thyge af Aarhus underskrev et brev på stedet. ${ }^{7}$ Måske fik Aarhusbispen allerede Tamdrup Kirke og gård som ejendom o. 1200, hvor det gyldne alter og Poppos relikvieskrin blev fremstillet. På det tidspunkt var Peder Vognsen biskop i Aarhus (1192-1204), og han var i slægt med Hviderne og ærkebiskop Absalon. Man kan forestille sig, at han fejrede overtagelsen af Tamdrup med fremstillingen af et relikvieskrin til den Poppo, som Saxo meget belejligt havde gjort til biskop i Aarhus. Desværre er der ingen skriftlige kilder, der kan bekræfte den mulighed.

\section{Udgravnings- og forskningshistorik}

I området omkring Tamdrup Kirke har der været foretaget en række arkæologiske udgravninger. Her følger indledningsvis en kort oversigt.

I 1983 blev der lavet en forundersøgelse vest for Bisgårdsvej og Tamdrup Kirkevej, fordi den historisk interesserede ejer af Tamdrup Bisgård, Jens Laursen, havde konstateret et område med høje fosfattal, der kunne tyde på aktivitet i 
fortiden. Vejle Kulturhistoriske Museum, der dengang havde det arkæologiske ansvar i området, lagde nogle søgegrøfter i efteråret 1983, der viste spor af bl.a. huse, og det førte til en udgravning i foråret 1984, hvor man åbnede to felter og yderligere to nord-syd orienterede søgegrøfter vest for den oprindelige. Desuden lagde man to søgegrøfter vinkelret på hinanden på marken syd for kirken og Bisgårdsvej, hvor der også var målt forhøjede fosfattal. ${ }^{8}$

På baggrund af nye observationer i 1990 lavede Horsens Museum en forundersøgelse vest-nordvest for 1984-udgravningen. Jens Laursen havde konstateret en koncentration af større sten i marken, der kunne være fra en grav. Man frilagde området med stenene og udlagde en øst-vest orienteret søgegrøft i foråret 1990. Stenene dækkede ikke over en grav, men viste sig at ligge i en naturlig lavning. I søgegrøften blev der til gengæld fundet spor af et hus, hvilket førte til åbning af et felt samt udlægning af yderligere søgegrøfter i sensommeren 1990. ${ }^{9}$

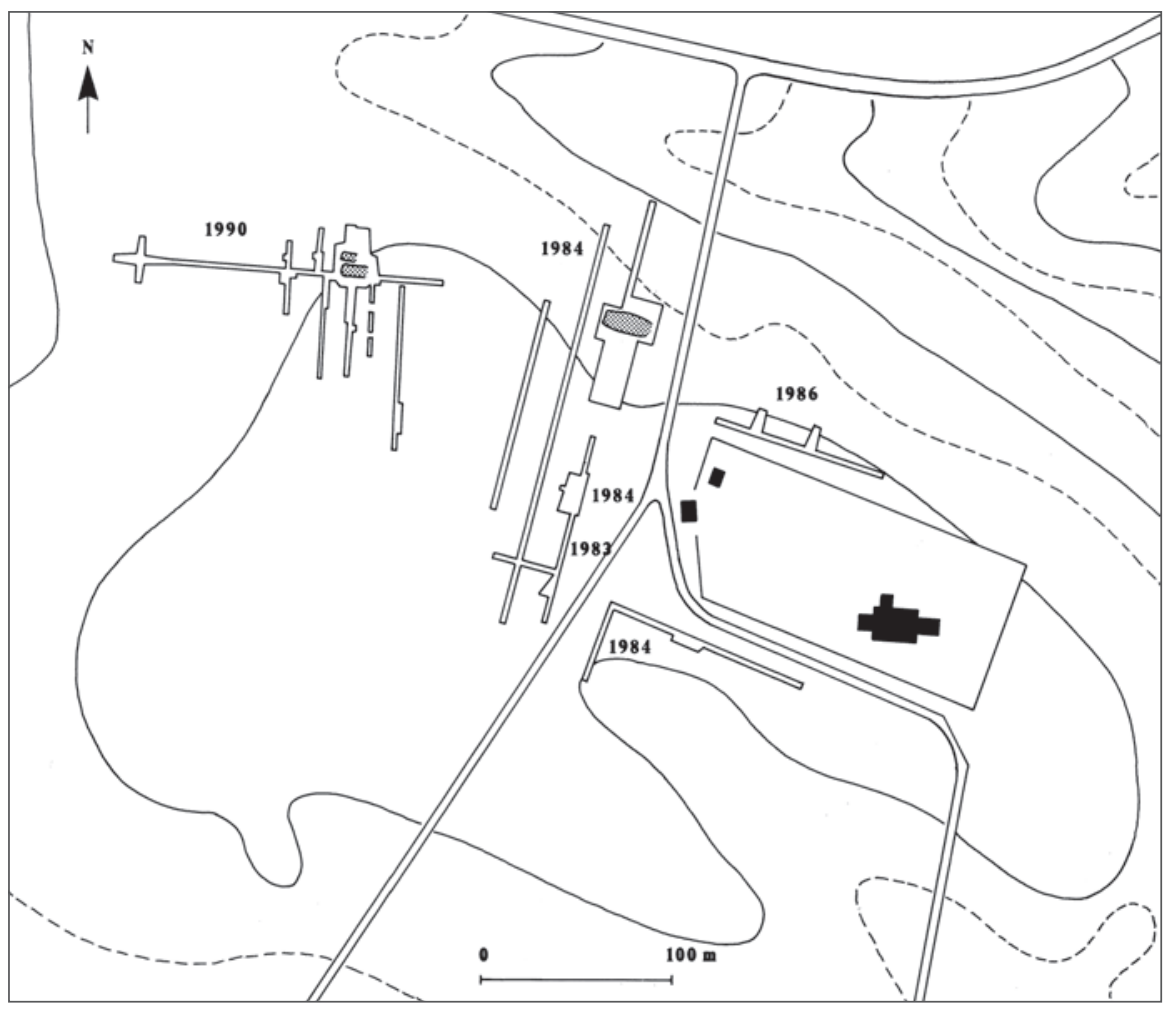

Fig. 4. Oversigtstegning over udgravninger 1984-1990. - Tegning: Søren Gottfred Petersen i Tamdrup. Kirke og Gård 1991.

Composite plan of excavations undertaken from 1984-1990. 
Foranlediget af udgravningsresultaterne fra 1984 og 1990, hvor der blev fundet spor af huse, blev der i 1991 foretaget endnu en forundersøgelse i området mellem og syd for udgravningerne. Desuden blev der trukket nogle søgegrøfter et stykke længere mod vest. Disse forundersøgelser førte ikke til videre udgravninger. ${ }^{10}$

Foranlediget af undersøgelserne fra 1984 og 1990 udgav Horsens Museum med flere i 1991 bogen Tamdrup - Kirke og gård. ${ }^{11}$ Tolkningen lød på, at man havde udgravet dele af en stormandsgård eller kongsgård, der havde ligget på stedet i sen vikingetid og tidlig middelalder, hvor også kirken var blevet opført (fig. 4). Man drog således paralleller til Lisbjerg og andre steder, hvor tidlige kirker var blevet opført i forbindelse med en stormandsgård. I beretningen fra 1991 var opfattelsen imidlertid, at denne tolkning måske var vel dristig, idet man i 1991-forundersøgelsen ikke mente at have fundet spor efter den vikingehal, man mente burde være der. Denne konklusion er dog aldrig blevet publiceret, og det er tolkningen i bogen, der indtil nu har været gældende.

\section{Detektorfund og forskningsprojekt}

I de senere år er der blevet indleveret en betragtelig mængde detektorfundne metalgenstande fra Tamdrup til Horsens Museum. Siden 2012 er der registreret 207 genstande, primært mønter, fibler, vægtlodder og beslag fra bl.a. hesteudstyr fra sen vikingetid og tidlig middelalder. Desuden blev der i 2013 udgravet en møntskat fra Svend Estridsens tid, og i den forbindelse foretaget en mindre arkæologisk udgravning af et $600 \mathrm{~m}^{2}$ stort område for at få indblik i møntskattens kontekst.

Museet har behandlet de indleverede detektorfund, der er blevet registreret og videreformidlet til danefævurdering. Da der imidlertid ikke har været ressourcer til en nøjere vurdering af genstandene, formulerede museet i 2014 et forskningsprojekt, som Kulturstyrelsen bevilgede penge til, således at der blev mulighed for at behandle materialet mere indgående. I formuleringen af forskningsprojektet blev der opstillet en tese, der bl.a. gik ud på, at Tamdrup i tillæg til stormands- eller kongsgården også kunne ses som central- og handelsplads. I den forbindelse måtte man også gøre sig tanker om Tamdrups rolle i forhold til den fremvoksende købstad i Horsens. Her var der en befæstet anløbsplads, hvis tidligste udvikling er sparsomt belyst. Der er dog C14-dateringer af den ældste voldgrav, der tyder på en funktionstid i 800- og 900-tallet, mens der ikke er spor af aktivitet i 1000-tallet. Kunne det være, fordi kongens interesse koncentrerede sig om Tamdrup? Efter at Niels-linjen mistede kongemagten i 


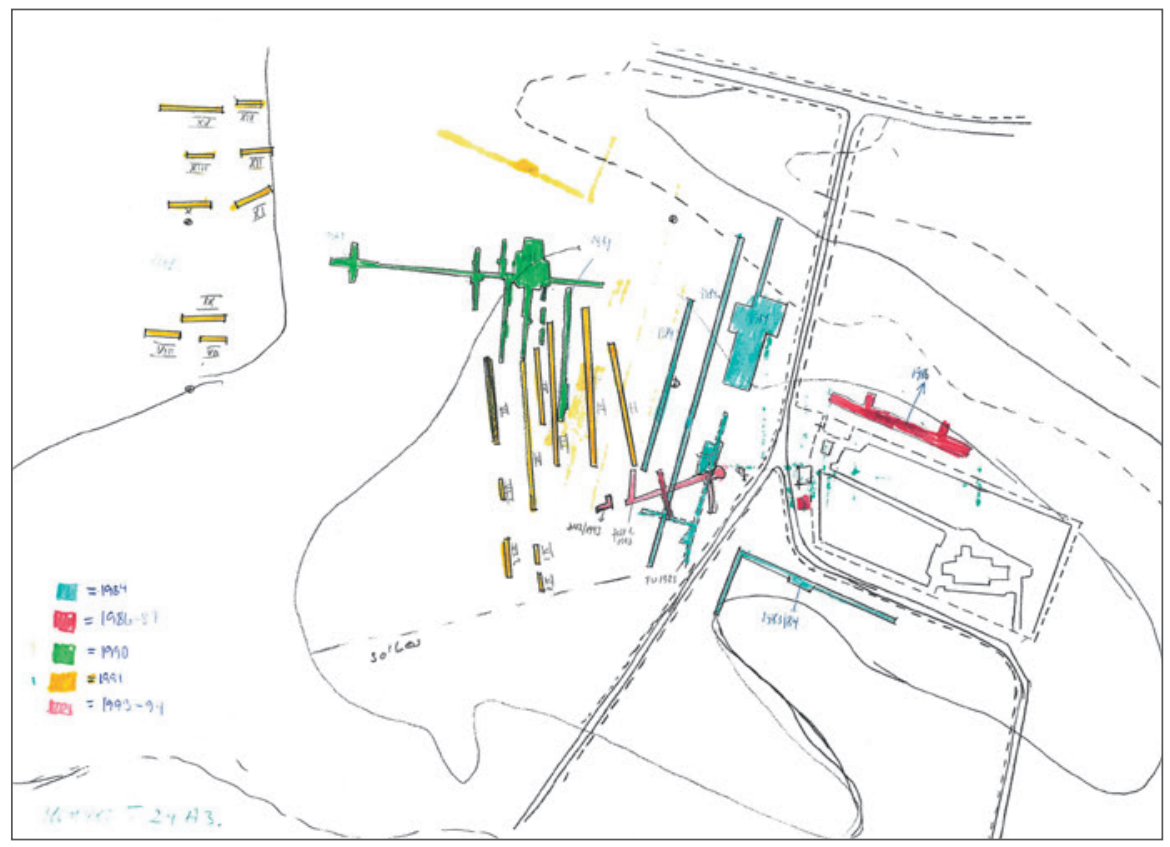

Fig. 5. Redigeret håndtegnet oversigt over alle udgravningskampagner 1983-1994. Ikke målfast. - Tegning: Horsens Museum.

Hand-drawn overview of all excavation campaigns from 1983-1994. Not to scale.

1134, flyttede fokus tilbage til Horsens, hvor vi ved, at både Svend Grathe og Valdemar den Store slog mønt.

Målet med forskningsprojektet har været at studere detektorfund og udgravningsresultater, både ved en analyse af det samlede fundmateriale, og ved en digitalisering af de gamle udgravningsplaner, så disse kunne sammenholdes med hinanden og med den nye udgravning. Herefter ville der være skabt grundlag for en samlet vurdering af Tamdrups funktion, rolle og betydning i sen vikingetid og tidlig middelalder.

\section{Nye tolkninger på grundlag af digitaliserede plantegninger}

I det følgende gives en redegørelse for det billede, der tegner sig, efter at de gamle planer er blevet digitaliserede, georefererede og samlet på én plantegning (fig. 6 og 7). 


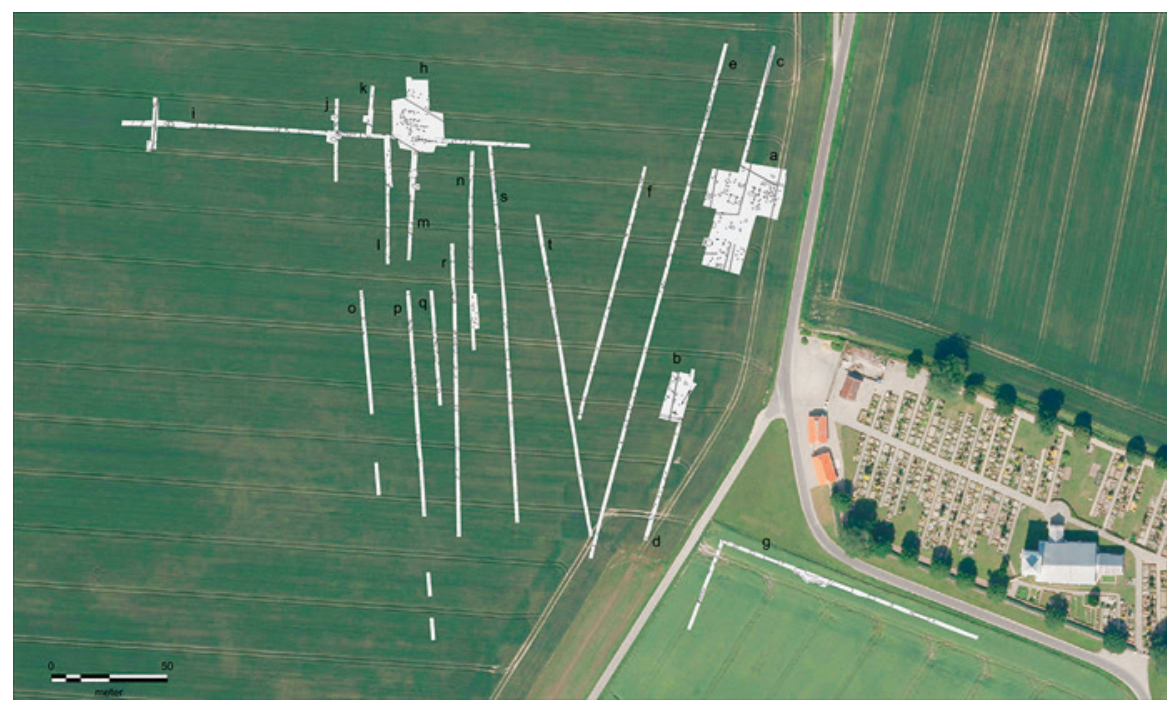

Fig. 6. Digitaliserede og georefererede søgegrøfter og felter 1983-1991 på ortofoto fra 2014. - Tegning: Lars Pagh.

Digitalised and georeferenced plan of trial trenches and excavation trenches from 19831991 on an orthophoto from 2014.

\section{4-udgravningen}

Mod øst langs Bisgårdsvej og Tamdrup Kirkevej blev der i 1983 lagt en nordsyd orienteret søgegrøft (d), som i 1984 førte til to felter (a, b) og yderligere tre søgegrøfter (c, e, f) mod nord og vest (fig. 7). I det nordlige felt (a) blev et langhus, et hegn og et grubehus fundet (fig. 8). Tolkningen af langhuset står ved magt, for så vidt at der er tale om et langhus med buede langvægge. Vestenden af huset synes entydig, men der kan være tvivl om husets østende. Man kan undre sig over, at de to østlige fag i den oprindelige tolkning har en afvigende orientering, og at nordvæggen derved får et atypisk forløb. Huset er $19 \mathrm{~m}$ langt, når man medregner de to østlige sæt tagbærende stolper. En alternativ mulighed er et 17, 5 m langt hus. Her udgår det østligste sæt tagbærende stolper. I stedet indgår et andet stolpehul som det nordlige i gavlen mod øst (fig. 8). Det giver et hus med regelmæssigt buede langvægge, hvor østgavlen $(4,3 \mathrm{~m})$ dog er smallere end vestgavlen $(5,3 \mathrm{~m})$.

I husets østlige del er der fundet spor af et ildsted, der viser, at huset har været til beboelse. Der er indsamlet trækul fra ildstedet, der potentielt kan bruges til C14-datering.

Umiddelbart vest for gavlen er der registreret et hegnsforløb parallelt med gavlen i nord-sydlig retning. Hegnet er registreret fra feltgrænsen i nord og ned 
forbi gavlen. Ved husets sydvestlige hjørne slår hegnet et knæk mod sydvest og fortsætter til feltgrænsen. Hegnet er formentlig samtidigt med huset. Det kan være et tofteskel, eller det kan indhegne et mindre område inde på en toft, som man kender det fra f.eks. Lisbjerg, hvor man har registreret en indhegnet lægård i forbindelse med hovedhuset. ${ }^{12}$

Overlappende med den østlige del af langhuset, forskudt $2 \mathrm{~m}$ mod nord, er der et muligt lille hus, $8,5 \mathrm{~m}$ langt og 4,5 m bredt, der ikke tidligere er blevet erkendt (fig. 8, hus 2). Måske har udgraverne ikke ment, at stolpehullerne passede sammen, eller måske er nogle af anlæggene udgået. Men umiddelbart virker det oplagt at tolke det som et hus på baggrund af plantegningen alene. Huset er ikke ret stort, men har alligevel tendens til let buede langvægge. Det må opfattes som et udhus og kan ikke have været samtidigt med langhuset. Dateringsmæssigt hører det dog også til sen vikingetid/tidlig middelalder, men må altså tilhøre en anden fase.

20 meter syd for langhuset er der spor af et grubehus med tagbærende stolper i øst og vest (fig. 8, hus 3). Grubehuset må have hørt til gården, og der er ikke

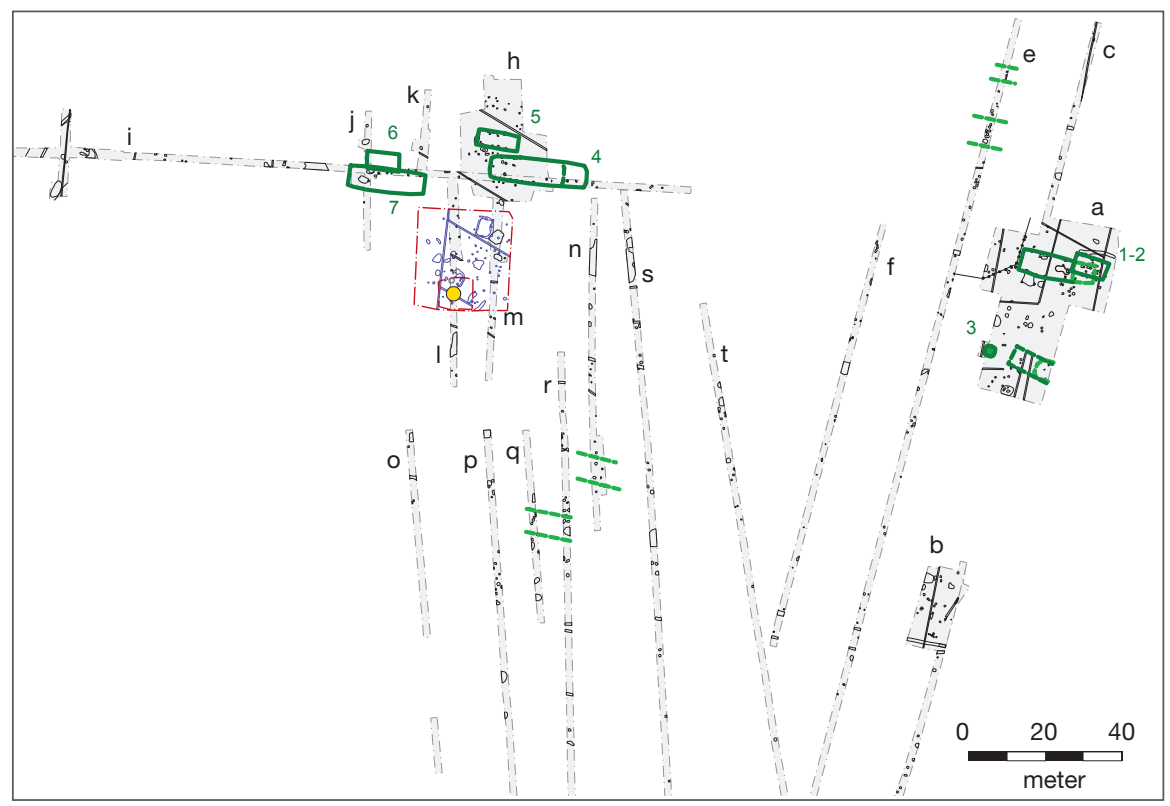

Fig. 7. Hustolkninger og møntskat (gul plet) markeret på digitaliserede planer 1983-1991 (grå felter) samt udgravningen af møntskatten 2013 (rød feltgrænse). - Tegning: Lars Pagh.

Interpretation of house remains and coin hoard (yellow dot) on digitalised plans from 1983-1991 (grey trenches) and the excavation of the coin hoard in 2013 (red trench boundary). 


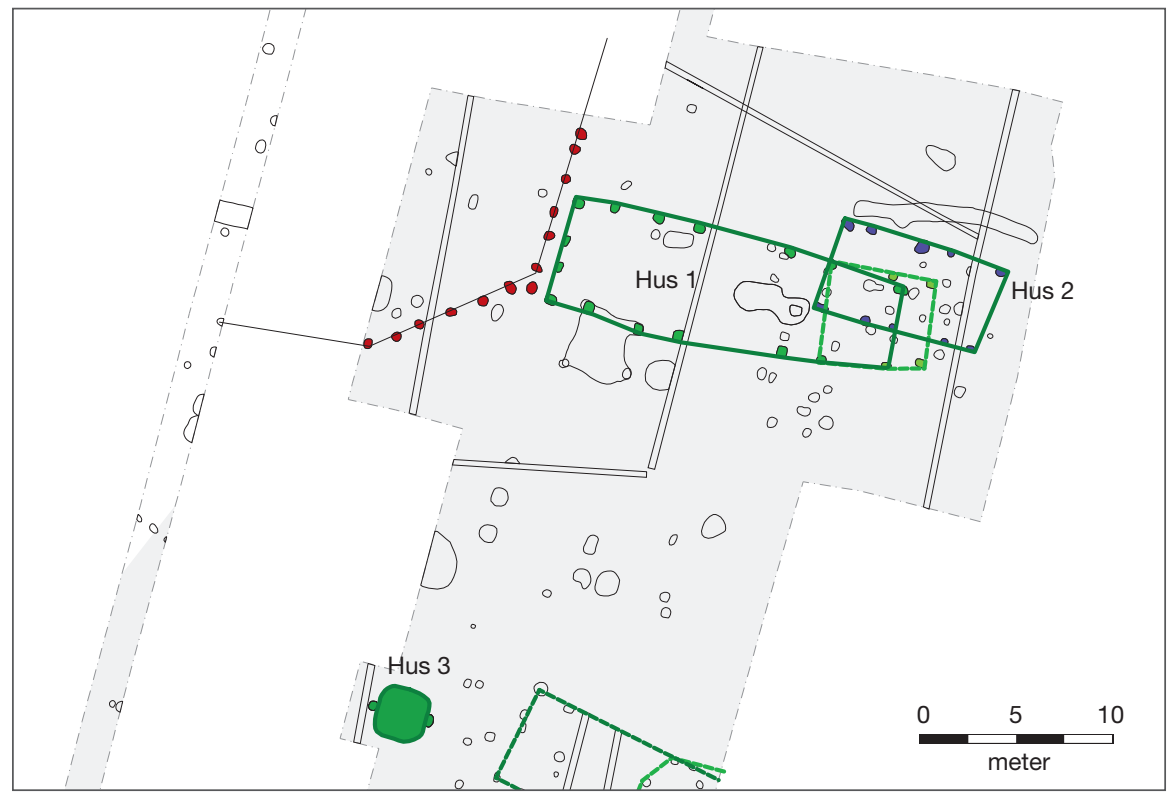

Fig. 8. Langhuset udgravet 1984 i alternativ tolkning (mørkegrønne stolpehuller). Den oprindeligt tolkede østende er vist med lysegrønne stolpehuller. Med blå stolpehuller er vist et mindre hus, formentlig en økonomibygning fra sen vikingetid/tidlig middelalder. Med rødt er markeret et hegn. For neden til venstre grubehuset registreret i 1984. Tegning: Lars Pagh.

Alternative interpretation of the longhouse excavated in 1984 (dark green postholes). The original interpretation of its eastern end is shown with light green postholes. The blue postholes mark a smaller construction, probably an auxiliary building from the Late Viking Age/Early Middle Ages. A fence is marked in red. Lower left, the pit-house recorded in 1984.

ændret noget i tolkningen af dette. På baggrund af keramikfund er grubehuset dateret til 1000-tallet.

Øst for grubehuset er der en del stolpehuller, der må være fra et eller flere huse. Her er der forskellige tolkningsmuligheder, der alle peger på, at stolpehullerne udgør den vestlige del af et eller flere huse. I flere af anlæggene nord for disse mulige huse er der fundet slagge og essesten, der tyder på smedeaktivitet i nærheden. I den sydligste del af feltet blev der registreret en rest af et kulturlag med mange fund, bl.a. af smedeaffald. Generelt var der fund af en hel del - formentlig hjemligt produceret - keramik i stolpehuller og gruber i hele feltet.

$50 \mathrm{~m}$ syd for feltet med langhuset blev der også åbnet et mindre felt i 1984 (b). Her såvel som i den tilhørende søgegrøft (d) blev der fundet en del stolpehuller, som ikke umiddelbart kunne sættes sammen til huse. Tilsammen er 
der dog så mange anlæg i denne sydlige del, at det er sandsynligt, at området hører med til bebyggelsen.

Nord for feltet (a) med langhuset blev der også anlagt en søgegrøft (c), hvor der var en del anlæg. Tilsvarende var der en hel del anlæg også i den nordlige

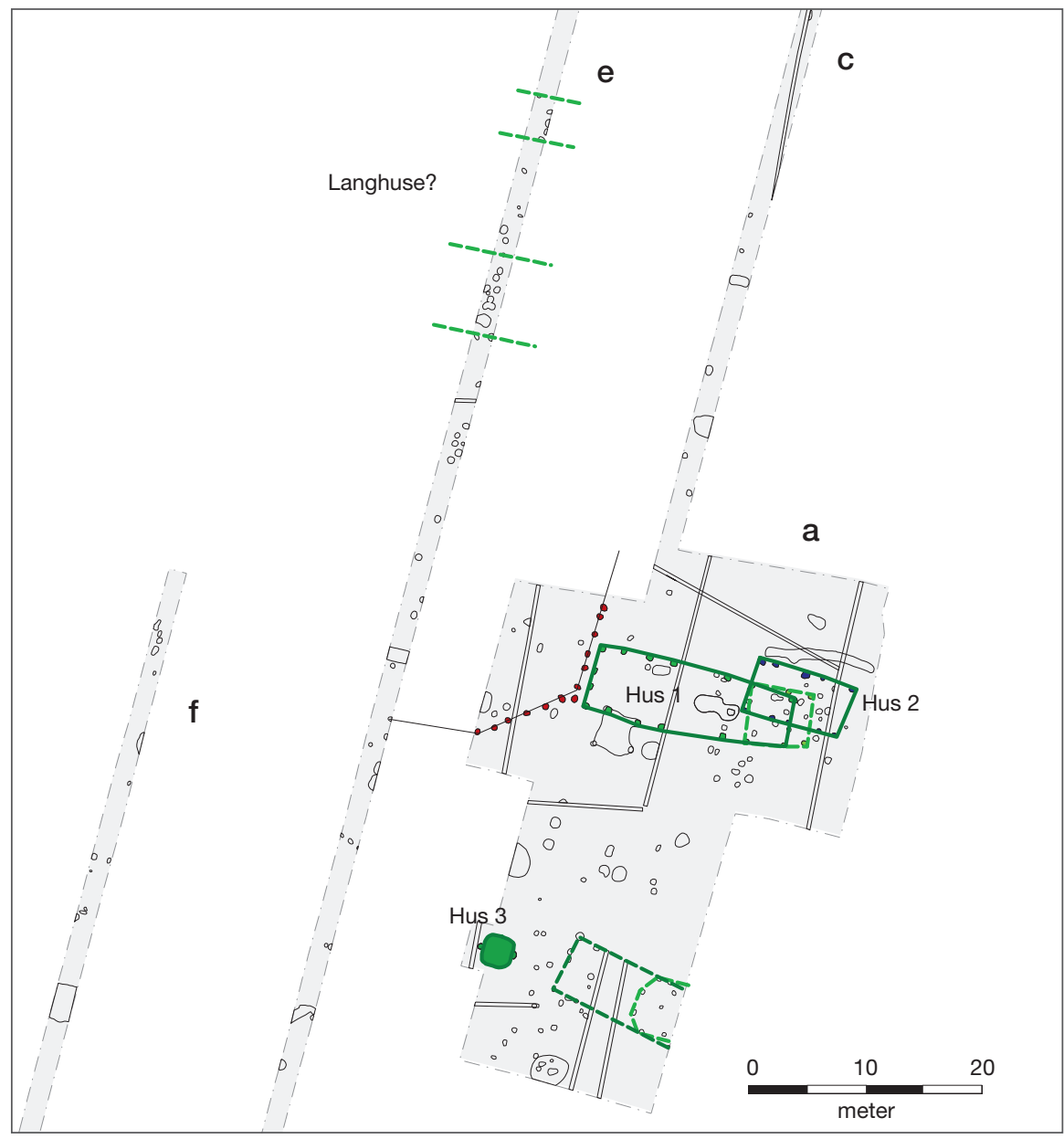

Fig. 9. Plantegning der viser det digitaliserede udgravningsfelt fra 1984. Hus 1 er langhuset med den oprindelige tolkning af østenden med stiplet linje. Hus 2 er den ny-tolkede økonomibygning. Hus 3 er grubehuset, og øst for dette er markeret mulige huse. I søgegrøft e er der med stiplede linjer markeret to mulige huse. Det sydligste af disse er et muligt hovedhus. - Tegning: Lars Pagh.

Digitalised plan of the excavation trench from 1984. 'Hus 1' is the longhouse, showing the original interpretation of the eastern end with a broken line. 'Hus 2' is the newly interpreted auxiliary building. 'Hus 3 ' is the pit-house and, to the east, possible buildings are marked. Two possible houses are marked with broken lines in trial trench e (Langhuse?): The southernmost is a possible main dwelling house. 
del af den midterste søgegrøft (e). I en grube i søgegrøft c fandtes der både et fragment af en bidselstang og en nøgle af bronze. Der var ikke tid eller råd til at udgrave disse områder i 1984, men det er overvejende sandsynligt, at der her findes spor af et eller flere huse (fig. 9). Hvis der er tale om et langhus, vil det passe med orienteringen af det ovennævnte mulige lægårdshegn. Her har vi altså et bud på beliggenheden af et muligt hovedhus, hvilket ikke passer ind i den overordnede tolkning fra 1991. Dette mulige hus ligger nemlig nord for den dengang formodede toftegrænse.

\section{0-udgravningen}

I maj måned 1990 blev der foretaget en mindre forundersøgelse vest for det $\mathrm{i}$ 1984 undersøgte område. På baggrund af oplysninger fra godsejer Jens Laursen, Tamdrup Bisgård, om høje fosfatværdier i og omkring en lille lavning, blev der udlagt to små, krydsende søgegrøfter (i) gennem lavningen. Her blev der fundet udsmidslag med ildskørnede sten og aske. Den øst-vest orienterede søgegrøft blev forlænget $150 \mathrm{~m}$ i østlig retning. Her blev der fundet en del anlægsspor, og et område med et formodet vægforløb af jordgravede stolper blev udpeget til nærmere undersøgelse. I august blev der åbnet i udgravningsfelt (h) i dette område, og det viste spor af to huse. Husene lå parallelt med hinanden i øst-vestlig retning og blev tolket som små økonomibygninger til samme stormandsgård som langhuset fra 1984-udgravningen. Det nordlige var $4 \mathrm{~m}$ bredt og det sydlige 5,5 $\mathrm{m}$ bredt. Begge huse blev anset for at være ca. $7 \mathrm{~m}$ lange og med åben østgavl. Det sydlige havde et sæt indvendige tagbærende stolper (fig. 4).

Nord for de to huse var der en række stolpehuller, der blev tolket som et muligt hegn.

I søgegrøften fra forundersøgelsen var der flere anlæg - stolpehuller, gruber og grøfter - end dem, der førte til udgravningsfeltet. Da man afdækkede udgravningsfeltet, lagde man fem nord-syd orienterede søgegrøfter (fig. 7, søgegrøft j, k, 1, m, n) vest, syd og sydøst for feltet (h). Der blev ikke foretaget yderligere, selvom der også var anlæg i mange af disse søgegrøfter.

Der er fundet en hel del hjemlig keramik i og ved husene i udgravningsfeltet og i søgegrøften mod vest. Desuden er der i et par større gruber i de to nordsyd orienterede søgegrøfter $(1, \mathrm{~m})$ syd for udgravningsfeltet fundet en hel del genstande i form af keramik, lerklining, tenvægte, et fragment af en vævevægt, et skebor og en halv hestesko af jern, smedeslagge og essesten. Typiske fund fra en gård, hvor man bl.a. har spundet og vævet som en del af husflidsarbejdet i en større husholdning, og hvor man har haft egen smedje. 
Nyfortolkning af 1990-udgravningen: Et Trelleborghus!

Udgravningen af de to huse i 1990 var det muliges kunst, da der ikke var de store midler til rådighed. Luftfotos fra den gang viser, at søgegrøften fra forundersøgelsen var dækket til, da udgravningen blev lavet. I dag har vi det fulde overblik over søgegrøfter og udgravningsfelter ved hjælp af de digitaliserede planer. Her viser det sig, at der i forundersøgelsen blev registreret nogle stolpehuller, der tilhørte det sydlige af de to huse, men som desværre ikke blev genfundet under udgravningen. Da disse stolpehuller således ikke blev en del af tolkningen, antog man, at huset var 7 m langt (fig. 10). Når man tager stolpehullerne fra forundersøgelsen med, tegner der sig grundplanen af et hus, der må tolkes som et Trelleborghus (fig. 11). Det oprindelige $7 \mathrm{~m}$ lange hus udgør vestenden af dette karakteristiske hus, mens resten af sydvæggen fandtes i søgegrøften. En del af nordvæggen mangler tilsyneladende, men resten af huset ser så overbevisende ud, at de manglende stolpehuller må tilskrives dårlige bevarings- eller observationsforhold. Den nordøstlige del af huset har slet ikke været afdækket, hvilket betyder, at det ikke kan siges med sikkerhed, om huset har været 19 eller 25 m langt uden støttestolper.

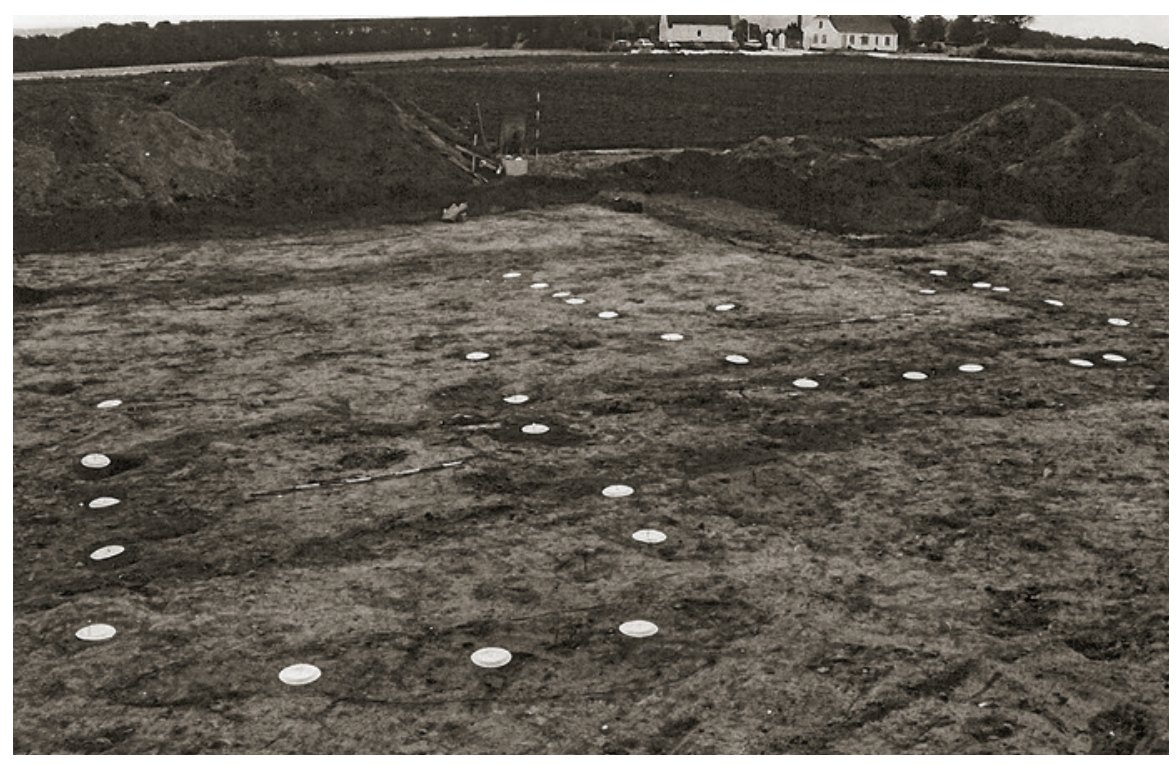

Fig. 10. Tolkning af hus 4 og 5, markeret med paptallerkner under udgravning 1990. - Foto: Horsens Museum.

Interpretation of houses 4 and 5 , marked with paper plates during the excavation in 1990. 


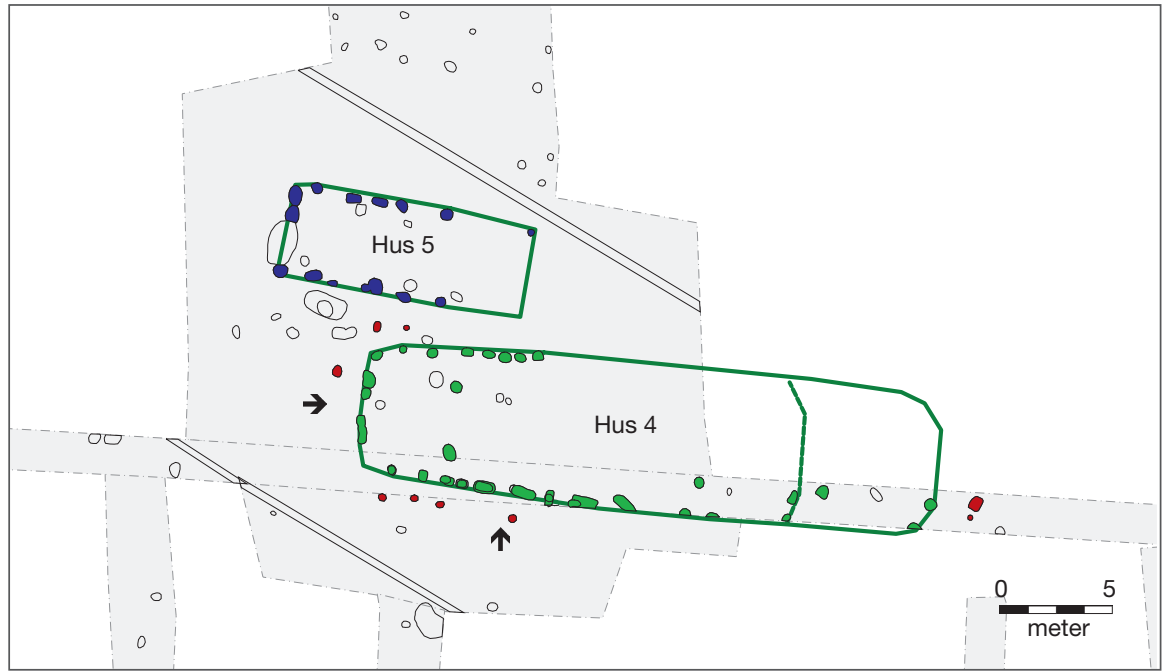

Fig. 11. Nytolkning af huse fra 1990-udgravningen. Det store langhus er et Trelleborghus. Vægstolper og tagbærende stolper er markeret med grønt og mulige udvendige støttestolper med rødt. Formodede indgange er markeret med pile. Østenden er usikker, og der er angivet to muligheder. Huset er 19 eller 25 m langt. Med blåt ses et udhus. I den nye tolkning er det 10,5 m langt og strækker sig længere mod øst end i 1990-tolkningen. - Tegning: Lars Pagh.

New interpretation of houses found during the 1990 excavation. The large longhouse is a Trelleborg house. Wall posts and roof-bearing posts are marked in green and possible buttress posts in red. Presumed entrances are marked with arrows. The eastern end is uncertain and two possibilities are shown. The building is either 19 or $25 \mathrm{~m}$ long. An auxiliary building is shown in blue. In the new interpretation, this is $10.5 \mathrm{~m}$ long and extends further to the east than in the 1990 interpretation.

Trelleborghuset har sit navn efter huse, der blev fundet under udgravningen af ringborgen Trelleborg på Vestsjælland. ${ }^{13}$ Typen forbindes traditionelt med Harald Blåtands regeringstid, hvor ringborgene blev opført, hvilket vil sige omkring 980, og er også senest fundet i Jelling. ${ }^{14}$ Efterhånden optræeder typen dog i så mange sammenhænge, at dateringen må bredes ud til at omfatte anden halvdel af 900-tallet og begyndelsen af 1000-tallet. Trelleborghuset har buede langvægge med skråtstillede udvendige støttestolper. I modsætning til jernalderens og ældre vikingetids treskibede huse, der havde indvendige sæt tagbærende stolper jævnt fordelt i hele husets længde, har Trelleborghuset kun to indvendige sæt, der deler huset op i et mindre gavlrum i hver ende af huset samt et stort rum eller en hal i midten. Typisk er der diagonalt placerede indgange i syd og nord ved hovedrummet, hvor der har været tilbygget vindfang. ${ }^{15}$ Desuden har der været indgangsdøre til gavlrummene i gavlene. 
Trelleborghuset har nogle konstruktive træk, som er nyskabende i forhold til tidligere tiders langhuse. Først og fremmest må Trelleborghuset have haft tagbærende spærfag, der har hvilet på tagremme over vægstolperne, for at kompensere for de manglende indvendige sæt af tagbærende stolper. ${ }^{16}$ Blandt arkæologer taler man populært desuden også om Trelleborg-agtige huse. Det er huse, der som minimum har den typiske grundplan med gavlrum og hovedrum og dermed må formodes at have haft den samme tagbærende konstruktion, men som mangler skrå støttestolper og/eller vindfang.

Trelleborghuset i Tamdrup var bedst bevaret i vestenden, hvor spor af vægstolper, gavlstolper og skillerum med indvendige tagbærende stolper var bevaret. Desuden var der spor af enkelte udvendige støttestolper. Der var spor af døråbninger i den sydvestlige ende af hovedrummet og i gavlen af det vestlige gavlrum, hvilket var helt efter bogen, men der blev ikke fundet spor af vindfang. Det kan skyldes dårlige bevaringsforhold, eller det kan skyldes, at huset har været uden vindfang. Hvis dette er tilfældet, kan huset ses som et Trelleborgagtigt hus, som ikke helt har fulgt forlægget, men som i sin grundlæggende, tagbærende konstruktion altså alligevel har været af denne type. Det formodes, at huset i Tamdrup er fra o. år 1000, idet det tolkes som værende inspireret af de Trelleborghuse, som blev bygget i ringborgene o. 980.

Trelleborghuse eller Trelleborg-agtige huse ser ud til at have eksisteret i et vist omfang i landbebyggelsen i den sene vikingetid. Det er usikkert, om typen opstår i forbindelse med ringborgene, eller om den allerede fandtes tidligere, for dateringen af typen er ikke endnu tilstrækkeligt dokumenteret. De senere år er der gjort en hel del nye fund af typen, således også i Horsens Museums område. Her er der fundet Trelleborg-agtige huse i Lund og Gedved. ${ }^{17}$ Begge steder er grundplanen helt efter bogen med hovedrum og gavlrum. I Lund mangler skråstolperne, og begge steder mangler vindfangene tilsyneladende, men fraværet af indvendige tagbærende stolper tyder på, at man også i landbebyggelsen har taget den nye konstruktionstype til sig.

I søgegrøften fra forundersøgelsen, vest for Trelleborghuset, er der stolpehuller, der må tilhøre et eller to ikke tidligere erkendte huse (fig. 12). I den vestligste af de nord-syd orienterede søgegrøfter (j) er der stolpehuller, der sammen med stolpehullerne fra forundersøgelsen formentlig er spor af en øst-vest orienteret, $8,5 \mathrm{~m}$ lang, etskibet økonomibygning (hus 6). Andre stolpehuller i forundersøgelsen kan være nordvæggen i et øst-vest orienteret $20 \mathrm{~m}$ langt langhus (hus 7).

I de to nord-syd orienterede søgegrøfter $(1, \mathrm{~m})$ syd for udgravningsfeltet er der stolpehuller, der kan være fra yderligere huse. Desuden er der i den østligste nord-syd orienterede søgegrøft (n) en del gruber og stolpehuller. Særligt må man hæfte sig ved nogle stolpehuller i den sydlige del, hvor der blev lavet en 


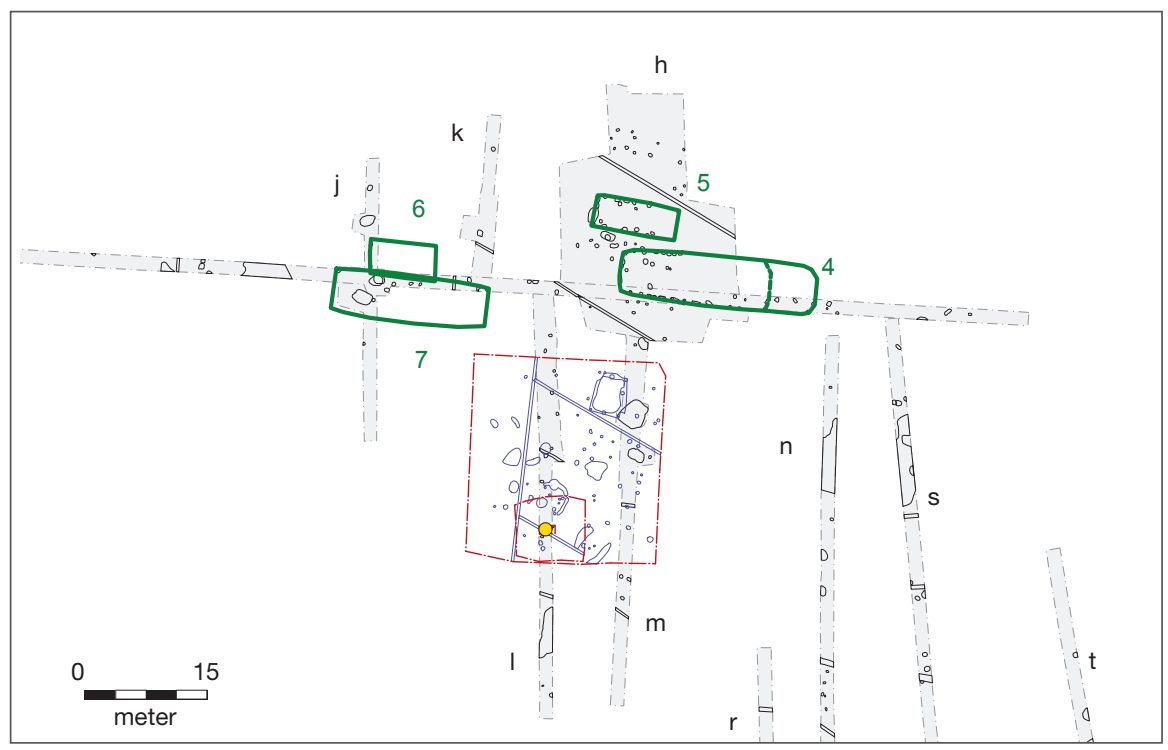

Fig. 12. Plantegning af udgravningsfeltet fra 1990 der viser de huse, der kan tolkes efter digitaliseringen. Feltet fra udgravningen af møntskatten i 2013 er vist med rød streg. Nordligst i dette felt ses grubehuset. Hus 4 er Trelleborghuset. Hus 6 og 7 er tolkningsforslag på baggrund af anlæg i søgegrøfterne. - Tegning: Lars Pagh.

Plan of the excavation trench from 1990, showing the houses that can be interpreted following digitalisation. The trench from excavation of the coin hoard in 2013 is marked with red lines. The pit-house lies in the northernmost part of this trench. 'Hus 4' is the Trelleborg house. 'Hus 6' and 'Hus 7' are suggested interpretations based on features in the trial trenches.

udvidelse af søgegrøften. At dømme ud fra plantegningen er der her et hus med bevarede vægforløb i nord og syd, et sæt indvendige tagbærende stolper og en bredde på knap 6,5 m (fig. 7). Hvis dette var fundet ved en forundersøgelse anno 2016, ville det uden tvivl blive udpeget til nærmere undersøgelse. Her er der også tale om en potentielt hovedhus.

\section{Udgravning 2013}

I forlængelse af tolkningen af 1990-udgravningen er det passende at se på den udgravning, der blev foretaget i forbindelse med fundet af møntskatten i efteråret 2013. Selve skatten bliver omtalt nedenfor under "Detektorfund", men digitaliseringen af 1990-udgravningen har vist, at skatten var placeret lidt SV for 1990-feltet.

For at få indblik i skattens kontekst blev der åbnet et $620 \mathrm{~m}^{2}$ stort felt, hvor der blev fundet spor af en del stolpehuller, primært nord og øst for skatten (fig. 12). Der var også en større kogestensgrube samt flere mindre kogestens- 
gruber. Desuden var der et grubehus $15 \mathrm{~m}$ nord for skatten. Selvom der var mange stolpehuller, var det ikke muligt at udpege sikre huse. Der var dog en del stolpehuller, som kunne udgøre vægforløb. De mulige vægforløb er rette, og der er ikke tegn på buede vægforløb. Der er fundet keramik, som er groft magret og ret blødt brændt og dermed typisk vikingetidskeramik.

Grubehuset er orienteret nord-syd med stolpehuller i kanten af nedgravningen til gulvet, centreret i hver gavl. Huset måler 4,7 x 3,5 m. Der er desuden stolpehuller i hvert hjørne uden for nedgravningen. Grubehuset er registreret med et tværsnit af nedgravningen til gulvet samt snit af stolpehullerne i hjørnerne. Der er fundet keramik, essesten og knoglefragmenter i fylden i selve huset. Der var ikke tid og råd til en komplet udgravning af grubehuset.

Som beskrevet i metodeafsnittet (appendiks) er der usikkerhed om georefereringen af 1990-plantegningerne, og derfor kan det ikke siges med sikkerhed, hvordan skatten var placeret i forhold til husene fra 1990. På plantegningen (fig. 12) er der ikke taget højde for, at 1990-plantegningen måske skal flyttes. Uanset kan man dog med ret stor sikkerhed sige, at skatten har været placeret 25-30 m syd for Trelleborghuset og de tilhørende mindre huse. Grubehuset fra 2013 må ligge bare 5-10 m syd for 1990-husene.

\section{1-forundersøgelsen}

På baggrund af udgravningerne i 1984 og 1990 regnede man som nævnt med, at man havde fat i en stormandsgård fra sen vikingetid. Man antog, at de udgravede huse lå længst mod nord på toften, og at man skulle søge gårdens hovedhus - i bedste fald kongens hal - i området mod syd mellem de udgravede huse. Man udlagde derfor seks nord-syd orienterede søgegrøfter (fig. 6, 7, søgegrøft o, p, q, r, s, t) i dette område. Resultatet var jf. beretningen nedslående: Man fandt ikke spor af Harald Blåtands hal. Anlæggene blev målt op i fladen, og feltarbejdet blev hurtigt afsluttet. Konklusionen var, at der ikke var anlægsspor, der kunne sættes sammen til større enheder som en formodet stormandsgård. Ingen af anlæggene blev undersøgt nærmere, hvilket blev begrundet med, at undersøgelsens formål udelukkende var at verificere eller afkræfte antagelserne efter 1990-udgravningen.

\section{Nye overvejelser omkring 1991-forundersøgelsen}

Når man 15 år efter en forundersøgelse ser på resultaterne med nye øjne, skal man være varsom med konklusionerne. Udgangspunktet er imidlertid, at der i området er gjort bemærkelsesværdigt mange detektorfund siden hen, som det vil fremgå nedenfor. Der er således god grund til at revurdere den gamle tolkning af 1991-forundersøgelsen. 


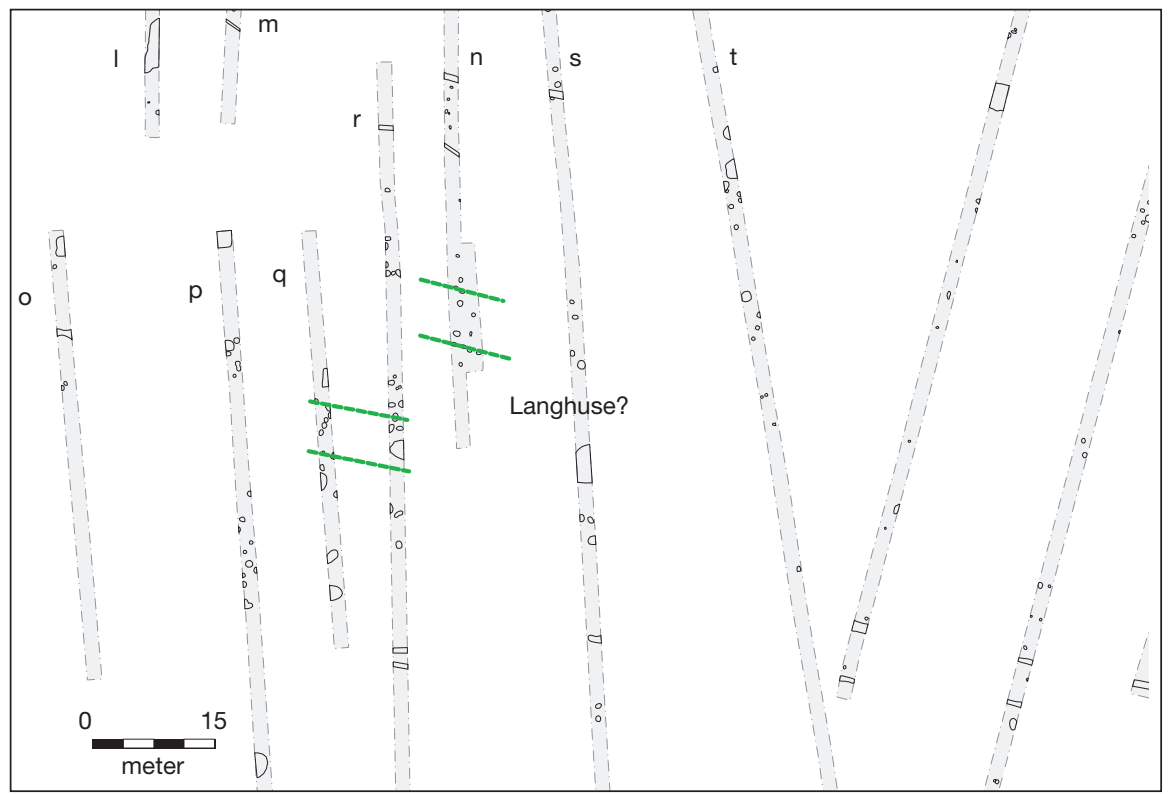

Fig. 13. Søgegrøfterne fra 1991-undersøgelsen efter digitalisering. Centralt i det undersøgte område ses nogle af de mulige hustolkninger markeret. - Tegning: Lars Pagh.

The trial trenches from the 1991 investigation after digitalisation. Some of the possible building interpretations are marked in the centre of the investigated area (Langhuse?).

Efter at have digitaliseret plantegningerne fra 1991 har vi et overblik over søgegrøfterne, som man ikke tidligere havde på samme måde. Det er eksempelvis tydeligt, at en koncentration af anlæg, primært formodede stolpehuller, er påfaldende i den centrale og nordlige del af de to midterste søgegrøfter (q, r) samt til dels også i den anden (p) og fjerde (s) søgegrøft fra vest. Her ville et par udvidelser af søgegrøfterne have været nyttige, men under alle omstændigheder ville man anbefale en egentlig arkæologisk udgravning, hvis man stødte på tilsvarende anlægsintensitet ved en forundersøgelse anno 2016. På samme måde er der også i den nordlige del af de to østligste søgegrøfter (s, t) en påfaldende udbredt forekomst af anlæg.

Efter at det hele er digitaliseret, er det nærliggende at se søgegrøfterne fra 1990 og 1991 i sammenhæng. Når man gør det, bekræftes billedet af den høje anlægsintensitet, især i de midterste 1991-søgegrøfter (fig. 13). Problemet er blot, at vi ikke kan være sikre på georefereringen af disse to årgange, og vi skal derfor være varsomme med at tolke direkte sammenhænge. Det mulige hovedhus i den sydlige del af 1990-søgegrøften (n) ligger meget tæt på området med de mange 1991-stolpehuller. Den nærliggende tolkning, at stolpehuller i 
4. og 5. søgegrøft fra vest i 1991-forundersøgelsen (r, s) er fra det mulige langhus i 1990-søgegrøften (n), er for vidtgående. Dertil er usikkerheden om især 1990-målesystemet for stor. Den forholdsvis sikre tolkning er, at de kommer fra den samme bebyggelse. Den samlede tolkning af 1990 og 1991 er, at der er stærke indikationer på bebyggelse i området for de midterste 1991-søgegrøfter. At der også er tale om et langhus, der kan udgøre et hovedhus, er bestemt en mulighed. Derfor må det konkluderes, at tolkningen af pladsen som en mulig kongsgård ser ud til at kunne bekræftes, selvom det ikke kan afgøres med sikkerhed uden nye udgravninger. Arkæologerne var skuffede efter 1991-forundersøgelsen, men med det overblik den moderne teknologi giver mulighed for, er tolkningen anderledes opmuntrende. Der er bestemt kraftige indicier for tilstedeværelsen af en kongsgård.

\section{Detektorfund}

Forståelsen af området ved Tamdrup Kirke fik tilføjet en helt ny dimension, da de første fund af metalgenstande ved hjælp af metaldetektor kom ind til Horsens Museum i efteråret 2011. Det var amatørarkæolog og detektorfører Finn H. Larsen, der var begyndt at afsøge marken primært vest for Tamdrup Kirke på vestsiden af Bisgårdsvej og Tamdrup Kirkevej. Efterhånden som genstandene kom ind, blev overvejelserne om stedets betydning og funktion i den sene vikingetid og tidlige middelalder taget op til revision. Tolkningen som stormandsgård var naturligvis kendt, men man var på Horsens Museum også vidende om, at denne tolkning efter 1991-søgegrøfterne var behæftet med nogen tvivl. Med de mange nye fund blev denne tvivl efterhånden gjort til skamme, samtidig med at man begyndte at overveje at tillægge pladsen flere funktioner. Var der tale om en handelsplads eller centralplads i forbindelse med gården? Og var pladsen i funktion tidligere end hidtil antaget?

Det er primært Finn H. Larsen, der har gået med metaldetektor på pladsen, men også Brian Kristensen har til tider deltaget. Begge har indleveret genstande til Horsens Museum, der er blevet sendt videre til danefæ-vurdering, og begge har indleveret genstande, der har betydning for forståelsen af pladsen, og som indgår i Horsens Museums samling, selvom de ikke er danefæ.

Spredningskortet antyder, at det meste af området er afsøgt, men detektorførerne har ikke lavet tracking af deres afsøgninger, så vi kan ikke dokumentere, hvor de har gået. Rent metodisk kan man derfor ikke være sikker på, om forskellene $\mathrm{i}$ intensitet af genstandsfund i forskellige dele af området er udtryk for reelle forskelle, eller om der også er forskel på, hvor grundigt der er afsøgt. Det 


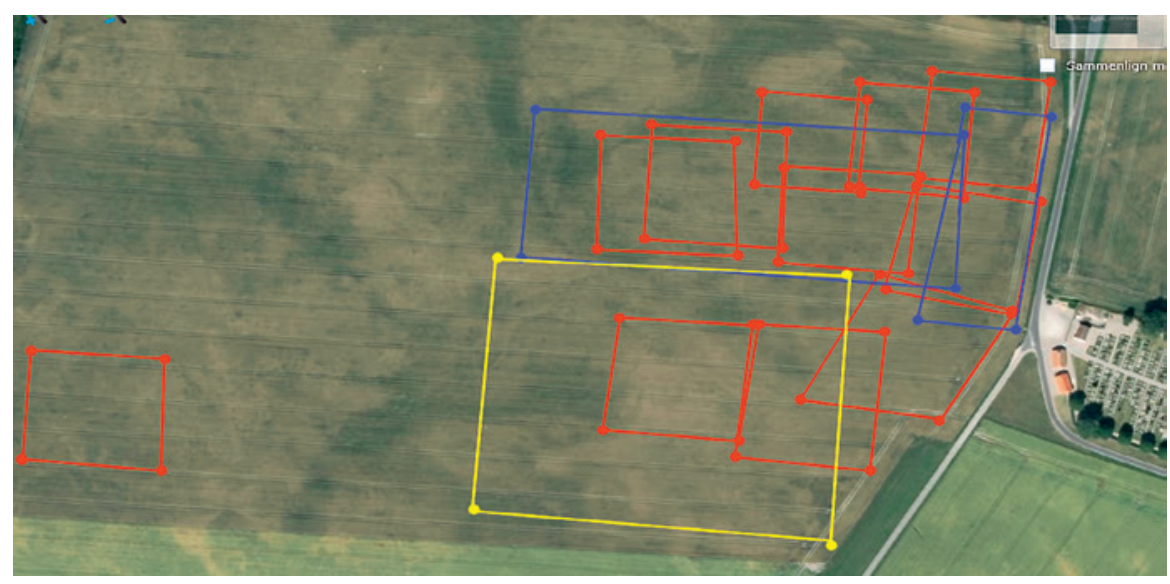

Fig. 14. Oversigt der viser, hvilke områder vest for Tamdrup Kirke der primært er afsøgt med detektor. Røde og blå felter er afsøgt, gult felt var planlagt (efterår 2015).

- Tegning: Finn H. Larsen.

Overview, showing the primary areas west of Tamdrup church subjected to metaldetector survey. Red and blue areas have been surveyed, surveys were planned for the yellow area (autumn 2015).

er formentlig en kombination af begge dele, der gør sig gældende. På kortet er den del markeret, der iflg. Larsen er grundigst afsøgt (fig. 14).

I det følgende vil materialet af detektorfundne metalgenstande fra perioden 2011-2015 blive præsenteret. I alt er der registreret 207 genstande (ultimo 2015). Desuden er der fundet en møntskat fra Svend Estridsens tid, dateret til o. 1060. Den består af 60 hele sølvmønter, klip og fragmenter, samt et endnu ikke udgravet præparat med et ukendt antal mønter.

De 207 metalgenstande fordeler sig på i alt 52 mønter (hele, klip og fragmenter), 34 beslag (hesteudstyr, rembeslag m.m.), 28 fibler (emaljerede skivefibler, urnes- og fuglefibler), 21 vægtlodder, 15 stykker sølv (barrer, brud, klip og støbetapper), 12 figurer (hængesmykker, små heste), 9 tenvægte, 8 bronzenøgler, 4 blyamuletter, 3 bronzebarrer, 2 fragmenter af foldevægte samt en række andre genstande her i blandt enkelte mere spektakulære som en guldring og en signetring af bronze. Dateringsmæssigt er de fleste genstande fra vikingetid og tidlig middelalder overvejende sen vikingetid og tidlig middelalder. For 178 genstande er dateringsrammen 800-1250. For 163 genstande er dateringsrammen 800-1150, heraf er 75 genstande fra perioden 800-1050 og 99 genstande fra perioden 900-1150. 46 genstande er dateret 1050-1550, heraf kun 12 med rimelig sikkerhed efter 1250. De fleste af disse 12 er borgerkrigsmønter (1250-1400), der er koncentreret i et område syd for vikinge- 
tidsbebyggelsen, hvor kirkestien til Vrønding har gået, jf. Generalstabens høje målebordsblad fra 1870'erne. Der er altså ingen tvivl om, at langt de fleste genstande er fra vikingetiden og den tidlige middelalder. Det tyder endvidere på, at hovedvægten inden for denne periode ligger i den sene vikingetid og tidlige middelalder. Det er således ganske få genstande, der med sikkerhed kan dateres til 800-tallet.

Det vil føre for vidt at redegøre for alle genstande endsige genstandsgrupper her. I det følgende vil de største grupper samt udvalgte enkeltfund af særlig interesse blive præsenteret.

\section{Mønter}

Den største genstandsgruppe er mønterne, hvoraf der er fundet 52. De fordeler sig på 24 hele mønter, 9 klip og 18 fragmenter samt 1 sammenrullet mønt (en arabisk dirhem). Dertil skal som nævnt lægges møntskatten, der blev udgravet i 2013. Møntskatten omtales særskilt nedenfor. Her vil i første omgang de løse mønter blive præsenteret.

Knap halvdelen af mønterne er altså hele, her i blandt alle borgerkrigsmønterne. Fordelingen mellem klip og fragmenter er lidt usikker, da det ikke i alle tilfælde kan afgøres med sikkerhed, om der er tale om et bevidst klip. I det følgende vil mønterne blive omtalt uden skelen til, om de er hele eller ej.

Borgerkrigsmønterne er af en kobberlegering, der gør, at de fleste er så irrede, at de ikke kan bestemmes, før de er konserverede. Der er dog en enkelt med et korsmotiv med dobbelt tværstav, der formentlig er fra Erik Menveds tid (1286-1319). Som nævnt er de fleste borgerkrigsmønter fundet i den sydlige del af området, hvor der har været en kirkesti mod Vrønding. De har formentlig ikke noget med bebyggelsen at gøre, men må være tabt af kirkegængere. Borgerkrigsmønterne vil ikke blive inddraget yderligere. Det samme gælder for den ene Christian II-mønt, der er fundet.

De resterende 41 mønter er af sølv. De fleste er bestemt af finderen og af Horsens Museum, men er endnu ikke vurderet af Danefæsekretariatet. En del er ikke bestemt, primært fordi de kun udgør små fragmenter. Der er fundet 13 Svend Estridsen-mønter, 5 Otto-Adelheid, 5 arabiske dirhems, 3 Skt. Colonia, 1 Knud d. Store, 1 Edvard Bekenderen, 1 Theodorich II, 1 Heinrich II, 1 Randpfennig, 1 romersk denar (med boret hul) samt 9 ikke-bestemte sølvmønter, hvoraf nogle dog ser ud til at være tyske og nogle danske/angelsaksiske.

Svend Estridsen-mønterne er umiddelbart den største gruppe af løse mønter. Man skal dog være opmærksom på, at langt de fleste mønter i møntskatten også var fra Svend Estridsen. Det kan ikke udelukkes, at nogle af de løse Svend Estridsen-mønter kan komme fra skatten. 


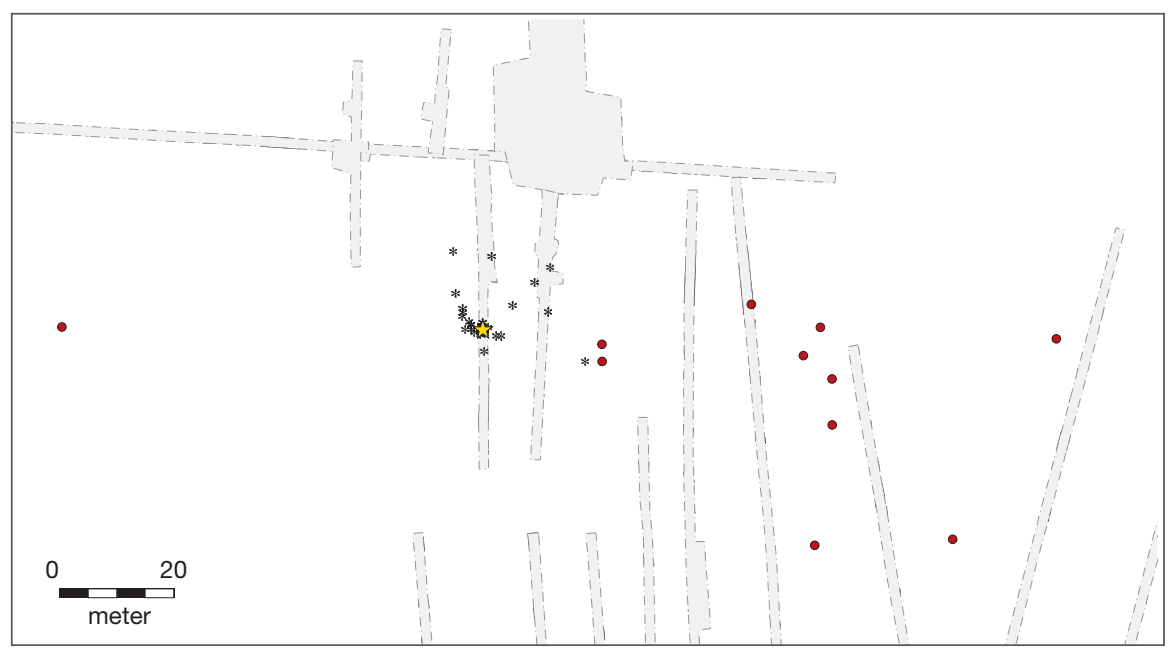

Fig. 15. Oversigt med møntskat og løse Svend Estridsen-mønter. Gul prik viser møntskattens nedgravning, der er taget op i præparat. Stjernerne viser løse Svend Estridsenmønter fundet i forbindelse med udgravning af skatten. Med rødt er vist de øvrige Svend Estridsen-mønter fundet på andre tidspunkter. Spørgsmålet er naturligvis, hvor mange af mønterne der reelt har været en del af skatten. - Tegning: Lars Pagh.

Overview showing the coin hoard and the single finds of Svein Estridson coins. The yellow dot marks where the hoard was buried: The hoard was taken up as a block. The stars mark single Svein Estridson coins found during excavation of the hoard. The other Svein Estridson coins, found at other times, are marked in red. But how many of these coins were actually originally part of the hoard?

I hvert fald to af de løse Svend Estridsen-mønter (X110 og X113) er fundet meget tæt på mønterne fra skatten og må nok betegnes som en del af denne (fig. 15). Også to andre mønter er fundet i umiddelbar nærhed af skatten, nemlig en Otto-Adelheid-penning (X64) og en kvart sølvmønt, der ikke er bestemt, men som ser dansk/angelsaksisk ud, og godt kunne være en Svend Estridsenmønt (X192). Derimod er den ene mønt, der er fundet et stykke mod vest, og de 8 mønter fra et begrænset område mod øst ikke nødvendigvis fra skatten, og især de 8 mønter mod øst skal snarere ses i en anden sammenhæng.

Tyske sølvmønter er der en del af fra Tamdrup. De er ikke identificeret af Nationalmuseet, men efter en foreløbig vurdering er 5 såkaldte OttoAdelheid og 3 Skt. Colonia. Disse mønter er præget under den tyske kejser Otto III (983-1002) og hans bedstemor Adelheid, der var gift med kejser Otto I der Große. Otto-Adelheid-mønterne blev slået i mange versioner helt frem til o. 1040. Formentlig er de lavet af sølv fra minerne på Rammelsberg ved Goslar. 


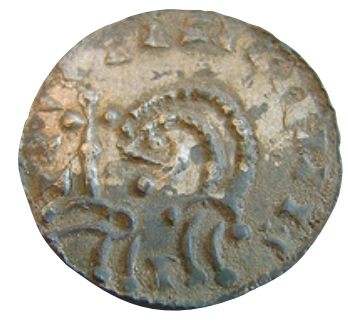

Fig. 16. Svend Estridsen-mønt (HOM 2844, X95), formentlig slået i Viborg. Skala 2:1. - Foto: Horsens Museum.

Svein Estridson coin, probably struck in Viborg.

Indtil mønterne er nærmere identificeret på Nationalmuseet, er dette en foreløbig tolkning. På den baggrund kan man forsigtigt konkludere, at de fleste løse mønter er fra det sene 900-tal og tidlige 1000-tal. De arabiske dirhems kan være fra 800- eller 900-tallet, men kan have været lang tid undervejs, før de endte i jorden i Tamdrup. Den romerske denar dateres 0-200 e.Kr. Der er dog boret et hul i den, og den har været anvendt sekundært som smykke, før den er endt i jorden. Kun Svend Estridsen-mønterne er fra anden halvdel af 1000-tallet, formentlig o. 1060, samt Edvard Bekenderen-mønten, der må være nogenlunde samtidig, idet denne engelske konge regerede 1042-1066. Bedømt ud fra de løse møntfund alene er den primære funktionsperiode altså slutningen af 900-tallet og begyndelsen af 1000-tallet, hvilket umiddelbart stemmer overens med Trelleborghuset.

\section{Møntskatten fra Tamdrup}

Som nævnt blev en skat af sølvmønter udgravet i Tamdrup i efteråret 2013. Detektorfund af nogle Svend Estridsen-sølvmønter førte til udgravningen af et skattefund, hvor selve nedgravningen til skatten blev taget op i præparat, og 60 løse sølvmønter blev registreret. Godt halvdelen var hele mønter, resten var klip eller fragmenter. Hverken de løse mønter eller præparatet er bearbejdet på Nationalmuseet (primo 2016). Tolkningen af skatten er Horsens Museums egen i samarbejde med finderen samt en foreløbig vurdering af enkelte af mønterne af Jens Christian Moesgård, Nationalmuseet, på baggrund af fotos.

De fleste mønter er fra Svend Estridsens tid og præget i Viborg. Indtil videre er der identificeret en del af typerne Hauberg 65 og 56A. Desuden er der en runemønt, Hauberg 6, præget i Lund (i Skåne, ikke Lund ved Tamdrup!) også præget af Svend Estridsen. Svend Estridsen var konge 1047-74, og på baggrund af Viborgmønterne skal skattens nedlæggelsestidspunkt formentlig dateres til o. 1060 . 


\section{Beslag}

Den næststørste fundkategori i Tamdrup er beslag, der er opgjort til 34 genstande. Denne kategori dækker dog over meget forskelligartede fund, hvoraf de mest dominerende er rembeslag af forskellig art samt beslag, der har med hesteudstyr at gøre. I alt er der med metaldetektor fundet 10 beslag eller fragmenter heraf, der menes at høre til hesteudstyr. Dertil kommer et enkelt fra udgravningen i 1984. Flertallet af disse beslag tolkes som dele af stangbidsler, hovedtøj og stigbøjler. Desuden er der en sporepig af bronze, der har siddet på en sporestang af jern.

\section{Hesteudstyr}

Beslaget, der blev fundet i 1984-udgravningen, er af bronze (fig. 17, M1113, X27D). Det består af et ovalt øskenhul med accentuerede knopper og en kort stang med en lille vulst, hvor beslaget er knækket af. Det blev tolket som et fragment af en hovedstang til et stangbidsel. Man antog den manglende del for at være en midterdel med et dyr i profil med et bagudvendt hoved, samt en modsvarende stang med øsken til den anden side. ${ }^{18}$ Et tilsvarende stykke er fundet i Lund (Skåne) og dateret til 1000-tallet. At denne tolkning ikke var helt i skoven, viste et detektorfund, der blev gjort i efteråret 2015. Her blev lige præcis sådan en del af en hovedstang fundet, man antog manglede i 1984 (fig. 18, X148). Det nye fund matcher dog ikke fragmentet fra 1984-udgravningen, men passer med sin slanke stang bedre til X196, der også er et nyt detektorfund. Alligevel er det sjovt, at man i 2015 finder et fragment, der svarer præcist til den del, man i 1984 antog manglede. 1984-fragmentet udgør med sin lidt kraftigere stang og lille vulst snarere halvdelen eller en fjerdedel af en mere enkel remdeler. Denne type remdeler kendes også fra Hvirring, beliggende blot $10 \mathrm{~km}$ vest for Tamdrup, hvor en fireleddet remdeler er fundet (fig. 19). I Tamdrup findes to fragmenter (X19 og X149) af denne type i det nye detektormateriale. Stilen hos både stangbidsel- og remdelerfragmenterne er så ens, at de må regnes for dele af det samme eller i hvert fald ensartede hesteudstyr.

En særlig udtryksfuld figur er fundet i Tamdrup i form af et rembeslag fra en stigbøjle, der er udformet på meget karakteristisk vis og forestiller et vikingeansigt (fig. 20). Ansigtet er vist lige forfra med markeret hjelm, øjenbryn, øjne, næse og et markant overskæg, der i enderne bøjer op. På begge sider af hjelmen er der pynt i gennembrudt arbejde, og nederst er der rester af jernnitter. Beslaget har siddet på stigbøjleremmen, der hvor den var fastgjort til den øverste del af stigbøjlen, hvor bøjlerne mødes. Stigbøjler fra vikingetiden kendes også som hele stigbøjler støbt i bronze, men denne type separate beslag er fra stigbøjler af jern med samlinger og beslag af bronze. 

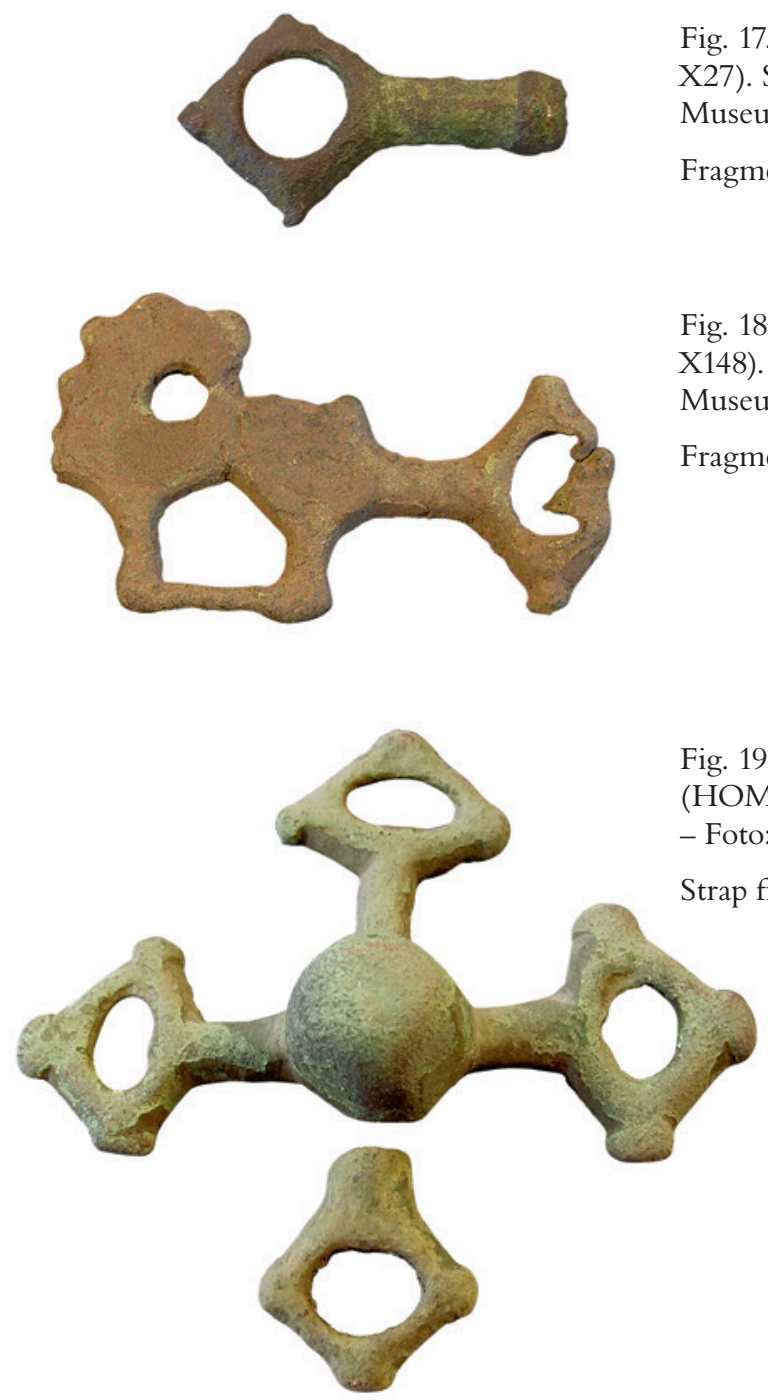

Fig. 17. Remdelerfragment (M1113 X27). Skala 1:1. - Foto: Horsens

Museum.

Fragment of strap fitting.

Fig. 18. Bidselfragment (HOM 2844, X148). Skala 1:1. - Foto: Horsens Museum.

Fragment of bit.

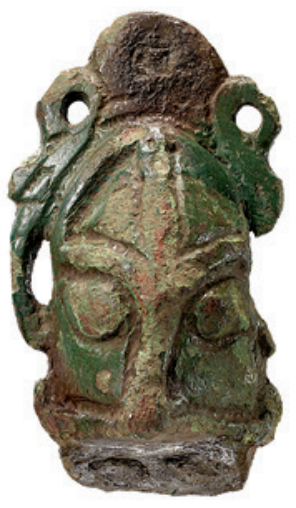

Fig. 20. Stigbøjlerembeslag af AngloSkandinavisk type med ansigtsmaske (HOM 2844, X91). Williams Class B, Type 4, East Anglian type face mount. Datering: 1000-tallet. Skala 1:1. - Foto: John Lee, Nationalmuseet.

Stirrup-strap fitting of AngloScandinavian type with face mask. Williams' Class B, Type 4, East Anglian type face mount. Date: 11 th century. 
Separate stigbøjlerembeslag kendes i hundredevis fra England, hvor de i 1997 blev typebestemt af David Williams. Stilmæssigt betegnes de som AngloSkandinaviske. Beslaget fra Tamdrup dateres til 1000-tallet og er et eksempel på en Williams Class B, Type 4, East Anglian type face mount. ${ }^{19} \mathrm{I}$ Williams' katalog er der registreret 12 beslag af denne type, hvoraf de 9 er fundet i East Anglia i det østlige England. Med den eksplosive forøgelse i antallet af detektorfundne metalgenstande de senere år, er der kommet væsentlig flere. En søgning på British Museums hjemmeside ${ }^{20}$ viser 19 nyere fund af præcis denne type.

I Danmark er der ikke nær så mange fund, selvom man også må formode, at stigbøjlerembeslag via detektorfund vil vise sig at være mere udbredt. Hidtil er der registreret fund af stigbøjlebeslag især fra Limfjordsområdet omkring Aalborg samt Roskildeegnen ${ }^{21}$. Af dem er kun et enkelt beslag med ansigt af samme type som beslaget fra Tamdrup. Det er fra Flengemarken ved Roskilde.

Der er fundet to forskellige korsformede beslag af bronze, der formentlig begge har fungeret som rembeslag i hovedtøj. De minder om de korsformede forgyldte remdelerbeslag, man kender fra rige ryttergrave, men der er fundet direkte paralleller til dem i England. Det ene, X40, er et beslag med tre bevarede men oprindeligt fire korsarme, der udgår fra en cirkulær midte med en central gennembrydning (fig. 21). Fra den cirkulære midte udgår mellem korsarmene fire karakteristiske små, krogede tapper. Omkring den centrale gennembrydning ses fire nittehuller med tilsyneladende bevarede rester af metalnitter, og i hver af de fire korsarme anes spor af huller, der er tillukkede af korrosion. To direkte paralleller er fundet på Isle of Weight og i Wiltshire (fig. 22). Beslaget kan tolkes som fire slanger, der snor sig ind i hinanden, således at de fire krogede tapper må være slangernes halespidser (fig. 21).

Det andet er ligeledes et beslag med oprindeligt fire korsarme ud fra en mere firkantet midte (fig. 23, X82). Her er der også en cirkulær gennembrydning og hertil fire omkring midten samt i korsarmene. Formentlig har der været nitter i hullerne til fastgøring af krydsende remme. En parallel til denne type
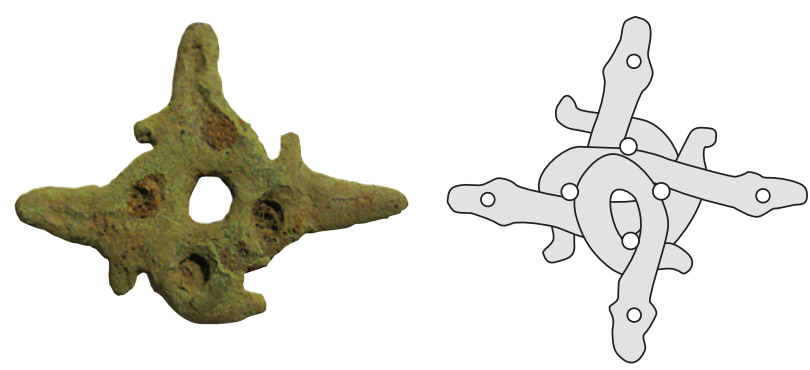

Fig. 21. Korsformet remdelerbeslag fra Tamdrup, X40. - Foto: Horsens Museum. Længde 4 $\mathrm{cm}$. Tolkningsforslag af korsformet remdelerbeslag, X40 fra Tamdrup. Længde 4 cm. - Tegning: Lars Pagh.

Cruciform strap divider from Tamdrup, X40. 

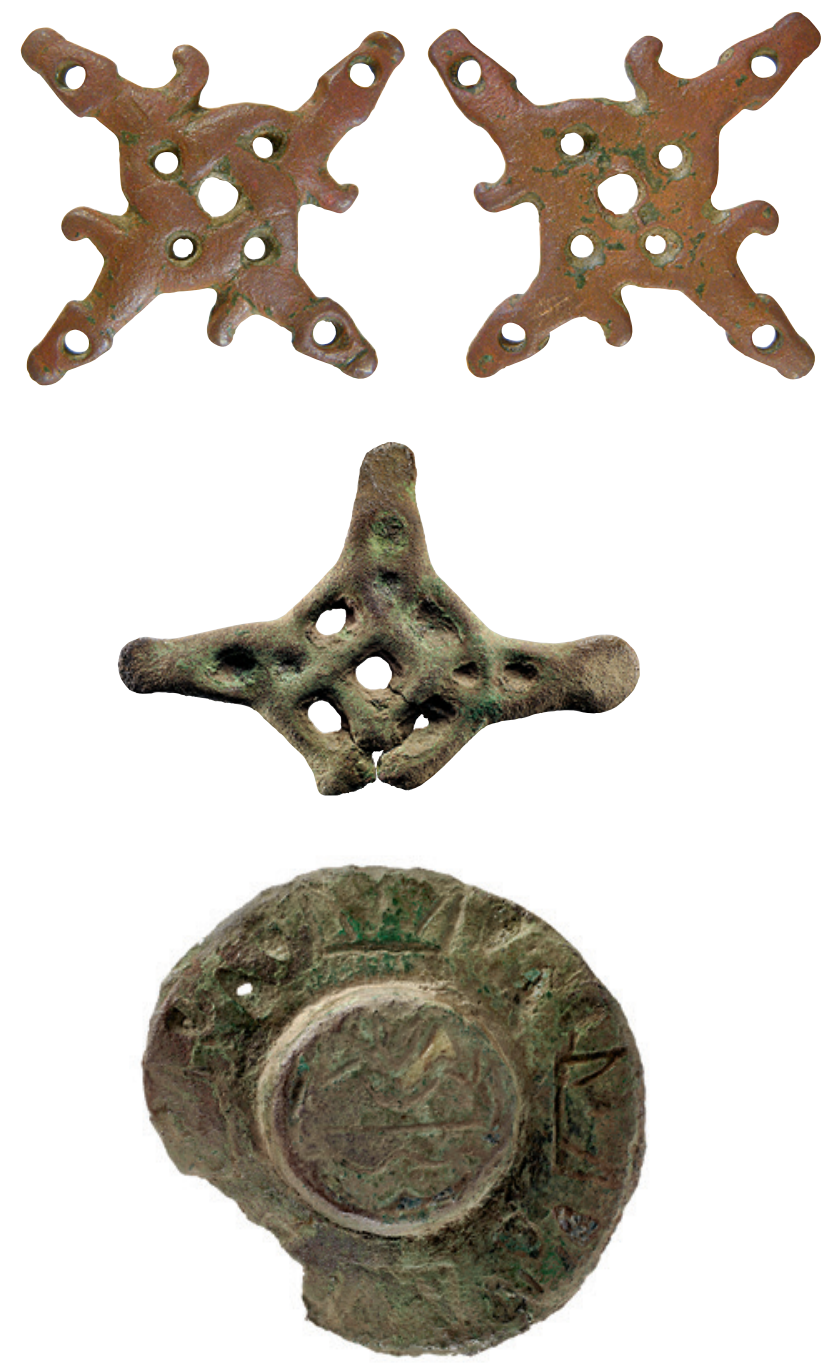

Fig. 22. Korsformet remdelerbeslag fra Wiltshire, England (WILTCF8956). Skala 1:1.

- Foto: www.finds.org. uk, copyright: Salisbury and South Wiltshire Museum.

Cruciform strap divider from Wiltshire, England.

Fig. 23. Korsformet remdelerbeslag fra Tamdrup (HOM 2844, X82). Skala 1:1. - Foto: John Lee, Nationalmuseet.

Cruciform strap divider from Tamdrup.

Fig. 24. Stor emaljefibel fra Tamdrup (HOM 2844, X88). Skala 1:1. - Foto: John Lee, Nationalmuseet.

Large enamel brooch from Tamdrup.

er fundet i Suffolk County i det østlige England, selvom det her formentlig fejlagtigt er tolket som et stigbøjlerembeslag i stil med de tidligere nævnte Anglo-Skandinaviske.

Af andre typer af beslag må nævnes tre dupsko samt andre former for formodede bælte- og remendebeslag.

\section{Fibler}

En kategori af særlige genstande udgøres af fiblerne. Fælles for denne kategori er, at det drejer sig om smykker, der ved hjælp af en nål på bagsiden har været fastgjort på tøjet til pynt eller for at holde sammen på et stykke klæde. Fiblerne er en markant kategori af genstande, som gennem tiden har ændret stil og 
Fig. 25. Stor emaljefibel fra Komjatice i Slovakiet. Skala 1:1. - Efter G. Waurich 1992.

Large enamel brooch from Komjatice in Slovakia.

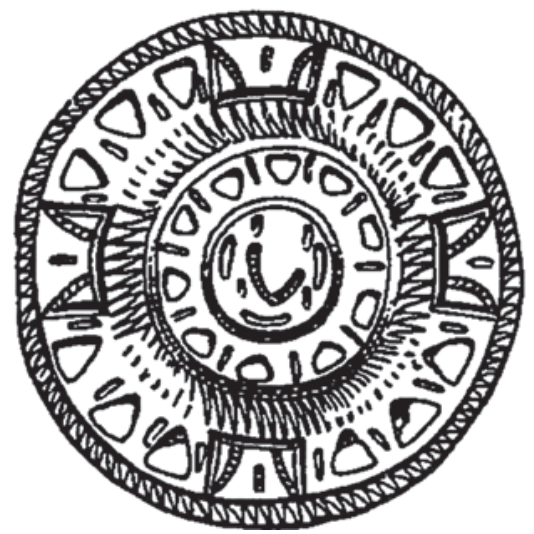

udseende. Dermed er de velegnede for arkæologer at bruge i dateringsøjemed. Således også fibler fra vikingetid og tidlig middelalder, som det handler om her.

\section{Emaljefibler}

I materialet fra Tamdrup er emaljefiblerne nogle af de mest iøjnefaldende. Af de $\mathrm{i}$ alt 28 fibler, der er registreret, er der 11 emaljefibler. Den mest usædvanlige er en stor skive-emaljefibel af en type, der formentlig ikke er fundet i Danmark tidligere - i hvert fald ikke at dømme ud fra det publicerede materiale (fig. 24). Alene størrelsen på fiblen (5,1 cm diameter) er usædvanlig. Centrum af fiblen er forhøjet i forhold til randen og forsynet med et mønster af tilsyneladende løsrevne figurer. På randen er der nogle modsatrettede sejlformede trekanter på en bundlinje, der danner fire kronelignende motiver og markerer en korsform. Mellem kronerne er der antydninger af små gruber, der formentlig har været emaljefyldte.

Der findes paralleller til denne type i Centraleuropa, og en af dem, der stilmæssigt kommer nærmest, er en fibel fra Komjatice i det vestlige Slovakiet, hvor den er fundet i en grav (fig. 25). ${ }^{22}$ Denne fibel har et stort set identisk kronemotiv, og selvom de øvrige elementer ikke er helt de samme, er ligheden slående. Dateringen er anden halvdel af 900-tallet og første halvdel af 1000-tallet.

De øvrige emaljefibler er velkendte typer af karolingiske og ottonske småfibler. Der er 4 cirkulære korsemaljefibler (fig. 26a), 2 stjerneformede skivefibler med central indfatning (fig. 26b), 1 plateauopbygget fibel med korsmotiv, 1 korsformet fibel med fem firkantede indfatninger samt 2 skiveformede fibler, hvor typen er usikker pga. dårlig bevaringsgrad. I Danmark er forekomsten af disse fibler efterhånden ret udbredt. Baastrup har kortlagt udbredelsen i flere omgange. ${ }^{23}$ I 2005 var der registreret 139 fund, i 2013 var tallet 197. Selvom typen bliver stadig mere udbredt, er de fleste fund stadig koncentreret om- 
Fig. 26a. Korsemaljefibel med spor af emalje i gruberne (HOM 2844, X48). Skala 1:1. - Foto: Horsens Museum.

Enamel cross-motif brooch with traces of enamel in the pits.

Fig. 26b. Stjerneformet skivefibel med central indfatning (HOM 2844, X46). Skala 1:1. - Foto: Horsens Museum.

Stellate disc brooch with central casing.

kring Ribe, Aalborg og Roskilde. Indtil 2013 var der kun registreret en enkelt i Østjylland (Skærmklint ved Jelling), men med de 10 fibler fra Tamdrup er Østjylland for alvor kommet på kortet.

\section{Dyrefibler}

Ud over emaljefiblerne er der 10 fibler, der med sikkerhed kan bestemmes som dyrefibler. ni af dem er af bronze, mens en enkelt er af sølv. Motiverne er fugle eller drager i nordiske dyrestilarter fra den sene vikingetid, urnes- og ringerikestil, samt mere enkle og naturalistiske former af fuglefibler fra sen vikingetid og tidlig middelalder. Dateringen er således for alle dyrefiblerne 1000-tallet og tidligt 1100-tal.

Der er et eksemplar af en type af fuglefibler, der kaldes fjerklodte og dekorerede fugle. ${ }^{24}$ Den er af bronze og er vist fra siden (fig. 27b, X127). Den har tydeligt markerede detaljer i fjerdragten, en løftet vinge og vifteformet hale. Den mangler hovedet og det forreste ben, som ellers ville have dannet en cirkelformet gennembrydning under fuglen.

En anden fuglefibel med fine detaljer er et velbevaret eksemplar i urnesstil (fig. 27c, X140). Den er af bronze, har slank hals, vifteformet hale og bærer præg af, at krop og vinger er flettet sammen, hvilket giver det karakteristiske urnespræg med gennembrydninger ved fødder, ryg og næb.

Mere stiliserede og ensformede fugle udgøres af to andre fibler af bronze fra Tamdrup (X136 og X190). Her er tale om fugle set fra siden med et silhuetagtigt præg uden markerede detaljer. Typen kendes i mange variationer og er formentlig lidt yngre end de ovennævnte typer og dateres til begyndelsen af 1100-tallet.

Der er fundet tre fibler, hvor motivet anses for at være drager. En af dem er en meget velbevaret bronzefigur, der tolkes som fibel eller anden form for pyntebeslag, idet det er usikkert, om der har været en nåleanordning på bagsiden (fig. 27a, X139). Dragen er set fra siden og i ringerikestil med tydelige detaljer på kroppen. Både hals og krop er markeret med langsløbende og 

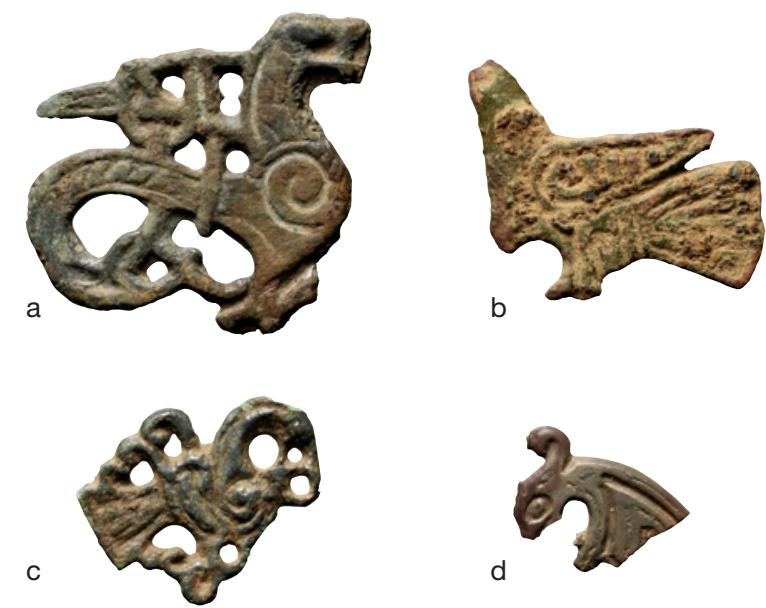

Fig. 27. Udvalg af fibler fra Tamdrup, fotograferet inden konservering. Øverst t.v. dragefibel, 3,5 cm (HOM 2844, X139), øverst t.h. fjerklædt og dekoreret fugl, $3 \mathrm{~cm}$ (HOM 2844, X127), nederst t.v. urnesfuglefibel, $2,5 \mathrm{~cm}$ (HOM 2844, X140), nederst t.h. fibel med dyremotiv, $1,7 \mathrm{~cm}$ (HOM 2844, X143). Skala 1:1. - Foto: John Lee, Nationalmuseet.

Selection of fibulas from Tamdrup, photographed prior to conservation. Upper left dragon fibula, $3.5 \mathrm{~cm}$, upper right feather-clad, decorated bird, $3 \mathrm{~cm}$, lower left Urnes bird fibula, $2.5 \mathrm{~cm}$, lower right fibula with animal motif, $1.7 \mathrm{~cm}$.

for kroppens vedkommende skrå tværfurer, og skulderleddet er fremhævet med en snegleform. Krop, hale og bagben er flettet sammen og giver sammen med det knejsende hoved dragen et levende udtryk. En tilsvarende dragefibel af bronze (X137) er mindre velbevaret og mangler bagkroppen/ halen, men har grundlæggende den samme form som den førnævinte. Den tredje dragefibel af bronze er en anden type, men anses også for at være ringerikestil, formentlig fra midten af 1000-tallet (X141). Den ses fra siden og står i en drabelig positur med bagudvendt hoved og munden på vid gab. Forkroppen og halsen er fremtrædende og accentueret af langsløbende furer og en snegleform ved skulderen.

Endelig skal nævnes en fragmentarisk men alligevel velbevaret dyrefibel af sølv (fig. 27b, X143). Kun hovedet og halsen er bevaret, og det er usikkert, om der er tale om en fugl eller en drage. En lille krølle i nakken leder tankerne hen på fine påfugle af sølv fra Toftegård på Fyn og Gresli i Norge. ${ }^{25}$ Også det let mandelformede øje i skarpt relief minder om disse påfugle. Til gengæld tyder halsen og den bevarede øverste del af kroppen alligevel på, at figuren er en anden. Stilen må være urnes og dateringen sen vikingetid/ tidlig middelalder. 
Fig. 28. Vægtlod af bronze med ornamentik fra Tamdrup

(HOM 2844, X6). Skala 1:1. - Foto: Horsens Museum.

Ornamented bronze weight from Tamdrup.

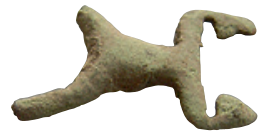

Fig. 29. Nøglefragment fra Tamdrup (HOM 2844, X193).

Skala 1:1. - Foto: Horsens Museum.

Fragment of key from Tamdrup.

\section{Andre genstande}

Der er fundet 21 vægtlodder i Tamdrup. Vægtlodderne har forskelligartet udformning. De findes som kugler, bipolare kugler, skiveformede, koniske, firkantede og facetterede på forskellig vis. Lidt over halvdelen er af bly, resten er af bronze, heraf et par eksemplarer med en kerne af jern og en ydre kappe af bronze (såkaldte ørtug-lodder), hvor jernet er "eksploderet" ud gennem bronzekappen. En af de bipolare kugler (fig. 28, X6) har ornamentik i form af små gruber på standfladen. Vægtlodder forbindes primært med handel, hvor det var vigtigt, at man kunne afveje en aftalt mængde sølv. Vægtlodder er imidlertid også blevet brugt i metalværkstederne, hvor det var afgørende at kunne afveje en bestemt mængde metal til en konkret støbning for at kunne opnå det rigtige forhold mellem de forskellige metaller i en legering.

Som vægtlodderne antyder, har der formentlig fundet en del handel sted i Tamdrup. Derpå tyder også - sammen med de mange mønter og møntfragmenter - fundet af 15 stykker brud- og klipsølv samt sølvbarrer. Det er en uensartet genstandsgruppe, der har det til fælles, at deres funktion har været den samme: De har fungeret som betalingsmiddel i en tid, hvor man ikke betalte med mønter med en pålydende værdi, men hvor metallet - primært sølv - havde en værdi, der blev målt i vægt. Denne form for vægtøkonomi blev afskaffet på Svend Estridsens tid i midten af 1000-tallet.

Nøgler af bronze er der fundet otte af, og de dateres alle bredt til vikingetiden (fig. 29). De fleste er fragmentarisk bevarede stykker af forholdsvis små nøgler af en ret enkel type, der må anses for at være fra skrin eller små kister. ${ }^{26}$ Nøgler blev forholdsvis udbredt i løbet af vikingetiden. Mange var af jern og en del af bronze. Alligevel er det et anseligt antal nøgler, der er fundet i Tamdrup.

Endnu en gruppe af genstande, der kort skal omtales, er tenvægtene. Det er en genstandsgruppe, der optræder mange steder, og som har været meget almindelig i vikingetiden. I arkæologiske udgravninger findes de ofte i brændt ler, mens tenvægte i metal - oftest bly - især er fundet med metaldetektor. I Tamdrup er der fundet ni tenvægte med metaldetektor. De er alle af bly og 

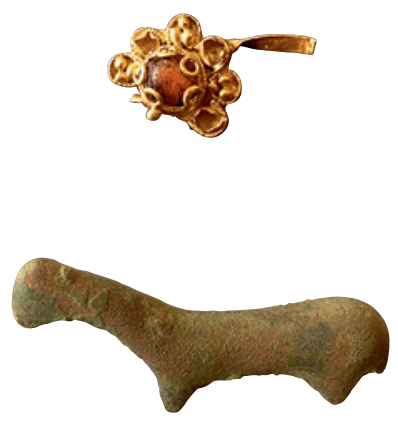

Fig. 30. Guldring fra Tamdrup (HOM 2844, X29). Skala 1:1. - Foto: Horsens Museum.

Gold ring from Tamdrup.

Fig. 31. Hestefigur af bronze, X30.

Skala 1:1. - Foto: Horsens Museum.

Bronze figure of a horse.

med hul i midten, og de fleste er i mere eller mindre udpræget grad koniske i form. Ved udgravningen i 1984 blev der fundet en enkelt tenvægt - af ler. Tenvægte er udtryk for, at der er spundet tråd til garn, hvilket var en helt almindelig husflidsaktivitet på en gård i vikingetiden.

Den fineste og absolut mest højstatusprægede genstand fra Tamdrup er en guldring, der er fundet ca. $60 \mathrm{~m}$ sydvest for langhuset i felt a (fig. 30, X29). Ringen er medtaget af de mange år i jorden, men man fornemmer alligevel dens pragt, efter at den er blevet konserveret. Selve ringen er knækket og bøjet og kun bevaret i knap $1 \mathrm{~cm}$ længde, mens dele af vedhæftningen er brækket af. Ringen består af en $2 \mathrm{~mm}$ bred og meget tynd guldring, mens vedhæftningen består af en central indfatning omkranset af oprindeligt otte cirkulære små indfatninger. I midten sidder en rød sten, formodentlig granat, indfattet i fem ringe. I en krans omkring stenen sidder de oprindeligt otte små, cirkulære indfatninger, hvoraf seks er bevaret. Hver anden har indfatninger, hvor stenene dog mangler, og hver anden indeholder tre små guldkugler. Indfatningernes kanter har fine tovsnoninger. Dateringen er lidt usikker, og derfor tillægges den heller ikke så stor udsagnsværdi. Den er dateret til senmiddalder/renæssance i danefæbrevet, men kan formentlig også være fra tidlig middelalder. Således har den træk, der minder om pragtbrochen fra Østergård, dateret til 1050. ${ }^{27}$

To andre spektakulære genstande er fundet i form af nogle små firbenede dyr, sandsynligvis heste, støbt i bronze. Disse figurer kendes fra det slaviske område og har formentlig haft en før-kristen, symbolsk funktion. ${ }^{28}$ Fælles for dem begge er deres langstrakte krop, lange hals og meget korte ben. Den ene (X3) er lidt klodset og grov i udførelsen, mens den anden er meget fin og elegant (fig. 31, X30).

Endelig skal nævnes fire blyamuletter. De er sendt til vurdering på Nationalmuseet og er ikke blevet behandlet endnu, men de er af en type, hvor der på et langstrakt stykke bly er skrevet en tekst med runer eller latinske bogstaver. 
Typisk står der en kristen besværgelse, der skal beskytte bæreren. Blyamuletten er foldet sammen og fylder ikke ret meget. Dateringen er middelalder (1100-1400), og to af dem er fundet i den sydvestlige del af den formodede vikingetidsplads, mens de to andre er fundet på marken syd for kirken.

\section{Sammenfatning}

Hvad fortæller genstandene os? De medvirker til at give en dateringsmæssig ramme for pladsen, de fortæller noget om, hvad der er foregået, de giver en indikation af, hvilke sociale klasser der var repræsenteret på stedet, og endelig giver de også et indblik i, hvilke fremmede forbindelser der kan have været til stede eller i hvert fald hvilke strømninger, man var påvirket af, hvilke netværk man var en del af. Men før man tolker for vidtgående, må man holde sig nogle metodiske vilkår for øje. For det første er det en bestemt type genstande, der er indsamlet. Det er kun metalgenstande, primært af andre metaller end jern. Man er med detektor gået målrettet efter æedle metaller og har kun indsamlet jern i mindre omfang. Kun i forbindelse med de arkæologiske udgravninger har man indsamlet genstande af andre materialer, primært keramik. Dette materiale er kun i overordnet form beskrevet i dette forskningsprojekt, som det fremgår af tolkningen af de gamle udgravninger. Man må også tage forbehold for, at metalgenstandene til en vis grad har flyttet sig i pløjelaget, ligesom det ikke er hele området, der er lige grundigt detektorafsøgt.

Når det er sagt, er der en masse information at hente. De fleste genstande er fra perioden 900-1100, og det er også dateringsrammen for pladsen som helhed, selvom der er genstande, der af forskellige grunde ligger udenfor denne ramme. Borgerkrigsmønterne og blyamuletterne er således fundet syd for det, der med vores nuværende viden udgør bebyggelsen. Det er dog ikke muligt at sige noget entydigt om en eventuel udvikling eller rumlig forskydning indenfor pladsen igennem de to århundreder. Der er en svag tendens til, at 900-tallets fund er mere homogent spredt på pladsen end 1000-tallets fund, der i lidt højere grad koncentrerer sig i den østlige del (fig. 32). Den tidlige middelalders fund er tilsyneladende koncentreret centralt på pladsen syd for de registrerede huse.

En del af fundene knytter sig til konkrete aktiviteter. Det gælder f.eks. vægtlodder og i udpræget grad tenvægte. Andre genstande har også haft praktiske funktioner, men knytter sig samtidig til højere samfundslag. Hertil må i materialet fra Tamdrup regnes hesteudstyret og nøglerne, mens de mange fibler og hængesmykker også hører til genstande, som primært folk fra samfundets højere lag havde adgang til. Mønter, brud- og klipsølv fandtes næsten alle steder i samfundet. De fleste havde formentlig mønter eller anden form for sølv i et eller andet omfang, i hvert fald i begrænsede perioder, men det var kun folk 


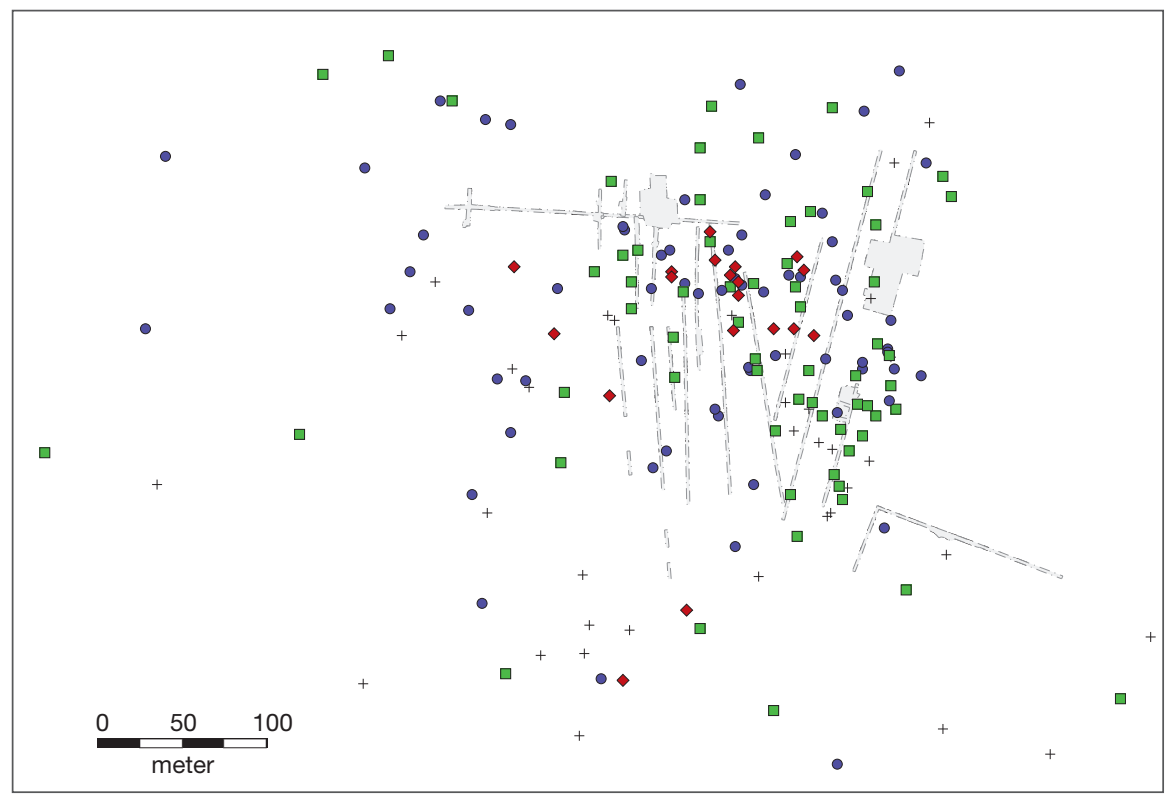

Fig. 32. Oversigt over alle detektorfundne genstande fra Tamdrup. Vikingetid 800-1050 (blå), vikingetid og tidlig middelalder 800-1150 (grøn), tidlig middelalder 1050-1150 (rød). - Tegning: Lars Pagh.

Overview of all metal-detector finds from Tamdrup. Viking Age 800-1050 (blue), Viking Age and Early Middle Ages 800-1150 (green), Early Middle Ages 1050-1150 (red).

fra de højere samfundslag, der havde sølv i større mængder, som Tamdrupskatten er udtryk for.

Mange genstande var formentlig fremstillet lokalt, men der er også en hel del, der er kommet langvejs fra. Genstande, der var importerede til lokalt brug, eller genstande der var medbragt og båret eller brugt af gæester eller handlende. En del hesteudstyr og fibler tyder på forbindelser til England. Som nævnt er der bl.a. fundet stigbøjlerembeslag og korsformede rembeslag til krydsende remme i Anglo-Skandinavisk stil, der har tydelige paralleller i det engelske fundmateriale. Den mest oplagte tolkning er, at man i Tamdrup har haft forbindelser til England. Hvordan disse forbindelser har set ud, kan der være mange forklaringer på. Folk fra England kan have gæstet Tamdrup, folk fra Tamdrup kan have hjembragt dem fra besøg i England, eller folk fra Tamdrup kan have erhvervet sig importerede engelske genstande.

Mønterne derimod peger i højere grad på kontakter til det tyske område. Fra slutningen af 900-tallet og begyndelsen af 1000-tallet er der en hel del tyske mønter, men forekomsten af Otto-Adelheid-penninge og andre tyske mønter 
er ikke nødvendigvis tegn på en direkte tysk forbindelse. Fra anden halvdel af 1000-tallet er det Svend Estridsen-mønter der dominerer, men de er primært danske. Man kan undre sig over, at der ikke er ret mange Knud d. Store-mønter på pladsen. De er til gengæld fundet i stort tal i det nærliggende Enner i forbindelse med en stor sølvskat. ${ }^{29}$ Andre genstande, der peger mod forbindelser til det vesteuropæiske område, er de emaljerede fibler i Karolingisk-Ottonsk stil. Igen kan der være tale om både importerede og lokalt fremstillede varer, men inspirationen er utvivlsomt vesteuropæisk. Til gengæld er der et mere eksotisk indslag i form af den særlige emaljerede skivefibel, som har sin eneste kendte parallel i et mellemeuropæisk fund fra Slovakiet. Måske er den kommet til Tamdrup via en vesteuropæisk forbindelse, der endnu en gang understreger de vidt forgrenede netværk, der fandtes i vikingetid og middelalder.

En del genstande tyder på handel i et vist omfang. Her er det igen mønterne og klip- og brudsølvet men også den forholdsvis store andel af blylodder, der må anses som relativt sikre indikatorer på handel, i hvert fald når man tager antallet i betragtning.

I lyset af detektorfundene må konklusionen være, at der er tale om en lokalitet, som har været beboet af personer af middel til høj status. Mange genstande var udenlandske eller udenlandsk inspirerede og tyder således på, at man i Tamdrup var del af et internationalt netværk. Genstandene støtter tolkningen af bebyggelsen som en stormands- og kongsgård. I dette miljø har man haft kontakter til resten af landet og det øvrige Norden, men det er især England og Vesteuropa, der slår igennem i genstandsmaterialet. Man må have haft udenlandske gæster, ligesom man har rejst ud. Som stormands- eller kongsgård kan Tamdrup også have fungeret som central- eller handelsplads. Det kan have været i forbindelse med udenlandsk besøg, eller det kan have været som lokalt marked på bestemte tidspunkter af året.

\section{Tamdrup i det datidige kulturlandskab}

Tamdrup har ligget højt i landskabet, tilbagetrukket fra kysten men alligevel med nem og hurtig adgang til Horsens Fjord. Man kunne nærme sig Tamdrup fra fjorden via Nørrestrand og Hansted Å i en nordlig rute eller via Bygholm $\AA ̊$ ad en mere sydlig vej (fig. 33). En tilbagetrukket placering var ikke atypisk i vikingetiden og den tidlige middelalder. Her kan man blot tænke på samtidens ringborge og Jelling, men også placeringen af kongsgården i Viby syd for Aarhus. På den tid fandtes der også pladser direkte ved kysten og i bunden af fjordene, hvor den tidlige urbanisering tog form med etableringen af de første købstæder, mens kongens pladser tilsyneladende skulle ligge lidt mere utilgæn- 


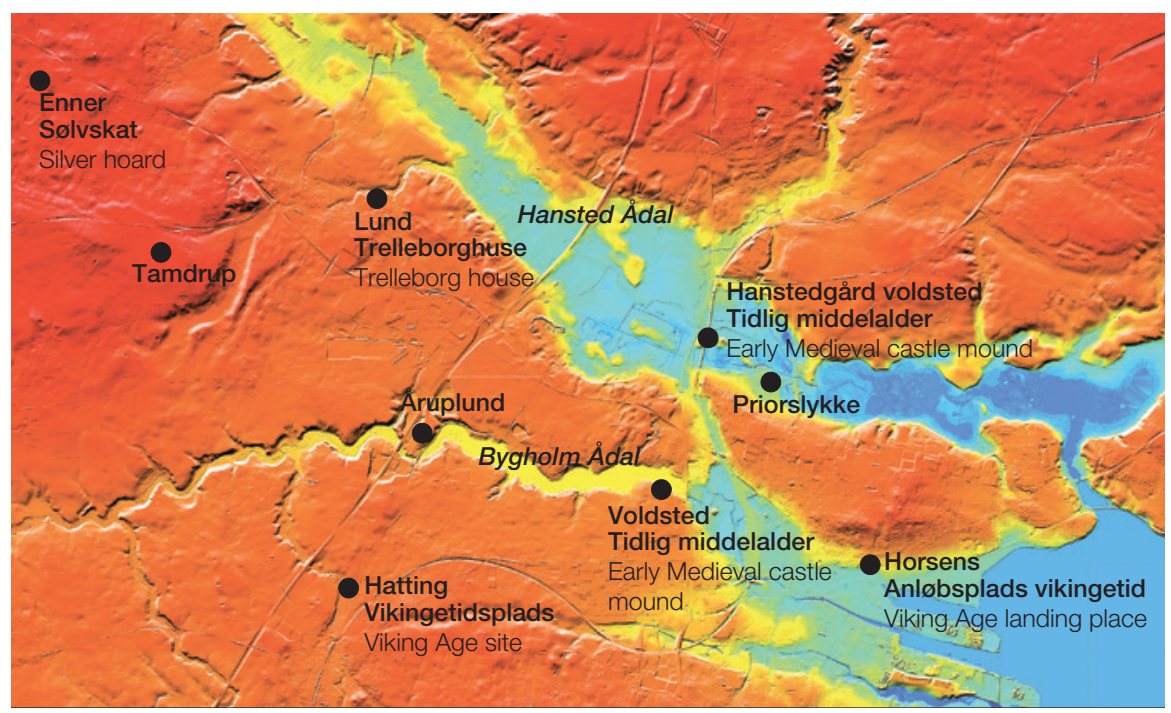

Fig. 33. Lidar højdekort med angivelse af lokaliteter med relation til vikingetiden omkring Horsens. - Tegning: Lars Pagh.

Lidar relief map showing localities associated with the Viking Age around Horsens.

geligt for sejlende. Som tilbagetrukne men centrale, regionale knudepunkter og markører mellem land og vand.

Den tidlige urbanisering af Horsens er ikke helt klarlagt, men en egentlig bydannelse er der formentlig først tale om i begyndelsen af 1100 -tallet. ${ }^{30}$ Til gengæld har der været en befæstet plads allerede i 800- eller 900-tallet, der hvor Horsens by senere blev etableret. Sejlede man imidlertid forbi denne plads og videre ind i Bygholm $\AA$, kunne man - til lands eller ved at trække skibene op ad åen - komme langt ind i landet. Bygholm eksisterede dengang ikke som hverken voldsted eller slot, ligesom opstemningen af Bygholm Sø, som den kendes i dag, først kom til i 1800-tallet. En middelalderlig vandmølle er der ikke fundet spor af. Der er i dag spor af et voldsted bare $100 \mathrm{~m}$ vest for den nuværende opstemning af Bygholm $\AA$ på sydsiden af søen. Dette kan have været et tidlig-middelalderligt voldsted - en forgænger til Bygholm voldsted og borg - til kontrol af trafikken ind i landet. På begge sider af Bygholm Å har der i dette område eksisteret sogne og kirker i tidlig middelalder, henholdsvis Lovby nord for åen og Tirup syd for åen. Begge kirker blev nedlagt allerede $\mathrm{i}$ middelalderen og sognene lagt under Hatting. Hatting er sogne- og herredsby, og i den nordlige udkant af byen, ved Hatting Bæk der løber ud i Bygholm $\AA$, er der udgravet en større handels- og produktionsplads fra vikingetiden 
med omkring 50 grubehuse og enkelte langhuse med buede langvægge og udvendige støttestolper. Man må forestille sig, at der har været en - arkæologisk ukendt - plads ved Bygholm Å, formentlig et sted vest for Årupgård, hvor man har kunnet lægge til med skibe, der blev trukket op ad åen, og hvorfra man hurtigt kunne komme til Hatting mod syd og til Tamdrup mod nord.

Fra Tamdrup var der nogenlunde lige hurtig adgang til Hansted $\AA$ og til Bygholm $\AA$, og det er sandsynligt, at man også har kunnet komme via Hansted Å, når man skulle til Tamdrup. På sydsiden af det sted, hvor Hansted Å løber ud i Nørrestrand, der er en nordlig sidearm til Horsens Fjord, har man arkæologisk udgravet den befæestede jernalderlandsby, kaldet Priorslykke. Måske har der eksisteret en anløbsplads på dette sted også i vikingetiden, eller måske har man trukket skibene længere op ad ån til et sted nedenfor landsbyen Lund. Denne har eksisteret i vikingetiden, og Horsens Museum har i 2007 fundet spor af Trelleborg-huse - dog uden udvendige støttestolper - i den nordlige udkant af Lund. På en banke midt i Hansted Ådal, lidt nord for Priorslykke, findes resterne af det middelalderlige voldsted Hanstedgård. Det vides ikke, om det har eksisteret i den sene vikingetid eller tidlige middelalder, men i givet fald kan det som det tidlige Bygholm have været brugt til kontrol af trafikken ind i landet.

Man må forestille sig, at Tamdrup har haft en høj status i 900- og 1000-tallet, hvor kongen har haft en gård og en trækirke på stedet. Et sted af så stor betydning, at det kulminerede med opførelsen af en treskibet romansk basilika til minde om kristningen af Danmark. Tamdrup ser ud til at have mistet sin betydning for kongemagten, kort tid efter at stenkirken stod færdig, hvilket kunne passe med, at Kong Niels som den sidste af Sven Estridsen-sønnerne blev dræbt i 1134, og en anden gren af kongeslægten overtog magten. Samtidig med at Tamdrup mistede sin betydning, blomstrede Horsens som by med så stor betydning for kongen, at både Svend Grathe og Valdemar d. Store slog mønt her. Tamdrup kan således have været en central del af den lokale topografi i vikingetiden, hvor Horsens har fungeret som anløbsplads, måske med sæsonhandel, og hvor en række pladser i en radius på 3-10 km omkring anløbspladsen har haft forskellige funktioner (fig. 34). Stednavne, der peger mod vikingetiden, kombineret med arkæologiske fund, alle fra vikingetiden, løfter lidt af sløret: Mod syd lå Tyrsted, hvor der er udgravet et metalværksted, C14-dateret til 1000-tallet, hvor man både har smedet jern og støbt i bronze. ${ }^{31}$ I Oens mod sydvest er der fundet langhuse og en jordfæestegravplads. Mod vest er den store produktionsplads i Hatting udgravet, i Tamdrup lå stormands-/ kongsgården, og i Enner er den store sølvskat fundet i nærheden af bebyggelse fra vikingetid og tidlig middelalder. I Lund mod nordvest er der fundet 


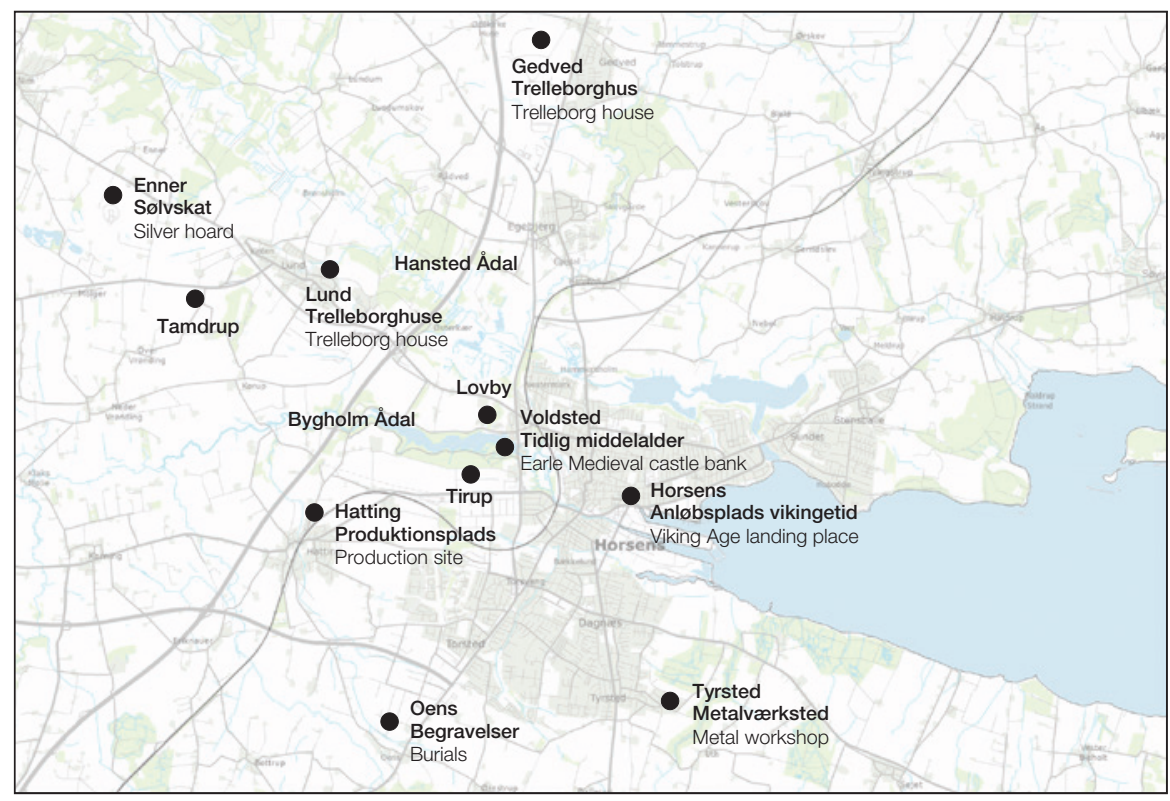

Fig. 34. Topografisk kort med angivelse af lokaliteter med arkæologiske fund fra sen vikingetid/tidlig middelalder omkring Horsens. - Tegning: Lars Pagh på baggrund af kort fra KMS.

Topographical map showing localities around Horsens with archaeological finds from the Late Viking Age/Early Middle Ages.

Trelleborghuse, og i Gedved, mod nord, er der også påvist et Trelleborghus. Der tegner sig et billede af et differentieret kulturlandskab, hvor agrare landsbyer og specialiserede produktionspladser, sammen med et højstatusmiljø i Tamdrup, har udgjort et lokalt netværk. Dermed har der været både en økonomisk og politisk interesse $\mathrm{i}$ at opretholde en befæstet anløbsplads i Horsens, hvor der kunne handles under ordnede forhold.

I det lange løb trak Horsens det længste strå, men det må formodes, at Tamdrup havde den højeste status i perioden 900-1100.

\section{Perspektiver}

Med forskningsprojektet har vi fået samlet og opdateret vores viden om Tamdrup. Digitaliseringen og georefereringen af de gamle plantegninger har vist, at de gamle tolkninger skulle revideres på flere væsentlige punkter. Samtidig har de vist, at potentialet er noget større end hidtil antaget. Der er registreret så mange anlæg i søgegrøfterne, at der utvivlsomt gemmer sig væsentlig mere 
bebyggelse på pladsen end det hidtil afdækkede. Den hidtidige datering af pladsen er delvist bekræftet men også forlænget bagud i tid, og vores opfattelse af den periode, pladsen har fungeret, er nuanceret en del.

Med projektet har vi også fået skabt et overblik over det detektorfundne genstandsmateriale fra pladsen. Det har givet svar på nogle spørgsmål om pladsens datering og funktion, men har også åbnet op for nye problemstillinger. Hvordan skal man f.eks. tolke den store andel af genstande, der tilsyneladende er importeret? I hvor høj grad er der blevet handlet på pladsen? Og er manglen på genstande, der med sikkerhed kan tilskrives det absolutte aristokrati, blot udtryk for, at vi endnu ikke har fundet dem, når nu indicierne på kongemagtens tilstedeværelse ellers er så stærke?

Der er masser af ubesvarede spørgsmål, men de tager alle udgangspunkt $i$, at vi faktisk har fået opdateret og forøget vores viden om stedet. Dermed er der skabt en ny platform, vi kan tage afsæt fra. En del af perspektiverne indebærer, at pladsen fortsat afsøges med detektor, og at vi i samarbejde med de dygtige detektorfolk bliver bedre til at systematisere afsøgningen. Endvidere må forskningsgravninger stå højt på ønskesedlen de kommende år. Med udgangspunkt i de georefererede plantegninger vil det være muligt at målrette kommende udgravningskampagner, så de giver de bedst mulige forudsætninger for at få belyst specifikke problemstillinger. I den forbindelse vil det også give rigtig god mening at forsøge at inddrage non-destruktive metoder som georadar eller magnetometer, og dermed "skanne" jorden med henblik på at supplere den viden, vi har fra de gamle udgravninger. Endelig vil en forskningsgravning være en kærkommen lejlighed til også at kunne anvende naturvidenskabelige metoder på pladsen. 


\section{Appendiks}

\section{Digitalisering og georeferering af gamle udgravningsplaner}

En væsentlig del af projektet har været at bearbejde de gamle udgravningsplaner og underkaste dem en samlet analyse. Der findes en oversigt på et håndtegnet kort, formentlig fra midten af 1990'erne, der viser placeringen af udgravningsfelter og søgegrøfter fra forskellige år fra 1983 til 1994 (fig. 5). Dette kort giver et godt overblik over de udgravningskampagner, der har været i Tamdrup. Ved nærmere eftersyn har det dog vist sig, at ikke alle felter og grøfter er placeret helt korrekt, og især 1991-søgegrøfterne er temmelig upræcist markeret. Oversigten viser felternes og søgegrøfternes omtrentlige placering, men ikke de enkelte anlæg eller konstruktioner. Den viser også, at der har været flere end de ovenfor omtalte undersøgelser i 1983/84, 1990 og 1991. Således var der også en mindre forundersøgelse nord for kirken i 1986 og nogle mindre undersøgelser i 1993/94 og igen i 1996. Det umiddelbart mest interessante fund ved disse undersøgelser har været en grøft med en øst-vestlig orientering, fundet i 1993 omtrent ved den sydlige ende af det sydlige 1984-felt, men det har ikke inden for rammerne af forskningsprojektet været muligt at placere den præcist. Her kunne der dog potentielt være tale om en afgrænsning af bebyggelsen mod syd.

Det var afgørende for det videre arbejde med de gamle plantegninger, at de blev både digitaliseret og georefereret, hvilket vil sige, at de skulle placeres nøjagtigt i forhold til et globalt, digitalt målesystem, så de kan sammenholdes med eksisterende og fremtidige GPS-opmålinger samt luftfotos og kort af nyere og ældre dato. Plantegningerne er blevet skannet og georefereret i computerprogrammet MapInfo, hvor alle museets opmålingsdata håndteres, og alle søgegrøfter og anlæg er tegnet i nye lag i MapInfo med de georefererede tegninger som baggrund (fig. 6).

\section{Målesystemer}

For at kunne vurdere om man kan have tillid til den digitalisering og georeferering, der er foretaget, er det afgørende at vide, hvor præcise de oprindelige målesystemer har været i forbindelse med de enkelte udgravninger. En fuldstændig redegørelse for målesystemerne ligger i en selvstændig rapport på Horsens Museum. ${ }^{32}$ Her skal blot redegøres for nogle overordnede præmisser. Som det vil fremgå, kan alle digitaliserede plantegninger anvendes - dog med forskellige forbehold.

Det grundlæggende målesystem for de kampagner, der er georefererede i forbindelse med forskningsprojektet, er etableret ved udgravningen i 1984. Målesystemet var oprindeligt lavet, så det var muligt at rekonstruere rimeligt præcist og var sikret vha. tre nedbankede jernrør. Det var nemt at finde det jernrør, der var placeret ved kirkegårdsdiget. Det befandt sig få $\mathrm{cm}$ under grusbelægningen på p-pladsen. Jernrøret ved Tamdrup Kirkevej kunne først lokaliseres $10 \mathrm{~cm}$ under græstørven efter anvendelse af metaldetektor. Det tredje jernrør kunne ikke genfindes. Siden 1984 er Nørre Snedevej ændret, så der nu er cykelsti på det sted, hvor jernrøret var banket ned, og det er gravet væk i den forbindelse. To jernrør, indmålt med GPS, var imidlertid nok til at rekonstruere målesystemet med stor nøjagtighed. ${ }^{33}$

Søgegrøfterne ved forundersøgelsen i 1983 er registreret på en oversigtstegning i 1:500, hvor de er tegnet i forhold til vejmidten af Tamdrup Kirkevej. Søgegrøfterne er georefereret i forhold til målesystemet fra 1984, men der er en forholdsvis stor fejlmargin pga. den upræcise indmåling. En samtolkning af anlæggene fra FU1983 og udgravning 1984 vil derfor være problematisk.

Jf. beretningen fra 1990 blev søgegrøfter og felter fra både forundersøgelse og udgravning målt ind i forhold til målesystemet fra 1984. Desværre findes oplysningen om nullinjens 
afstand til jernrørene fra 1984 ikke, og der er således en del usikkerhed forbundet med at bruge dem. Ved udgravningen i forbindelse med fundet af sølvskatten i $2013 \mathrm{blev}$ felt og anlæg målt med GPS. Efter at have digitaliseret plantegningerne fra 1990 var der håb om, at felterne overlappede. Ved nærmere granskning ser det ud til, at der kan erkendes et overlap ved søgegrøft 1 (fig. 7), men det kræver, at den georefererede plantegning fra 1990 flyttes $12 \mathrm{~m}$ mod øst og 1,4 m mod nord. $12 \mathrm{~m}$ kan lyde af meget, men svarer blot til $2 \mathrm{~mm}$ på en tegning, når målestoksforholdet er 1:5000 som i tilfældet med tegningen fra bogen.

Georefereringen af 1990-plantegningerne er under alle omstændigheder behæftet med nogen usikkerhed. Måske skal de flyttes jf. ovenstående, men i plantegningerne i nærværende projekt er 1990-plantegningerne uændrede i forhold til georefereringen. De kan bruges med forbehold, indtil de måske en dag kan efterprøves ved en ny udgravning eller afprøvning af non-destruktive metoder som georadar. Men under alle omstændigheder skal det understreges, at de er helt valide i forhold til at vurdere 1990-felter og søgegrøfter indbyrdes og i relation til forundersøgelsen 1990. Det i sig selv er værdifuldt og har givet anledning til nye konklusioner, som det vil fremgå af det foregående.

Forundersøgelsen 1991 er også indmålt i forhold til målesystemet fra 1984. Det har været muligt med nogenlunde nøjagtighed i MapInfo at konstruere placeringen af hovedlinjen, og man kan formentlig have tillid til, at georefereringen af 1991-forundersøgelsen er rimelig præcis.

\section{NOTER}

1. Schiørring 1991.

2. Danmarks Kirker 2002.

3. Lund 2006, s. 6.

4. Lund 2006, s. 7.

5. Danmarks Kirker 2002, s. 5062.

6. Danmarks Kirker 2002, s. 5044.

7. Danmarks Kirker 2002, s. 5043.

8. Dokumentation for udgravningen findes på Horsens Museum, sagsnr. M1113.

9. Dokumentation for udgravningen findes på Horsens Museum, sagsnr. HOM 483.

10. Dokumentation for udgravningen findes på Horsens Museum, sagsnr. HOM 483.

11. Schiørring 1991.

12. Jeppesen 2004, s. 164.

13. Nørlund 1948.

14. Jessen, Andersen, Pedersen, Jensen og Holst 2011.

15. Skov 1994.

16. Jessen 2015, s. 193.

17. Dokumenteret i ikke-publicerede beretninger: HOM 2109, Langgade 25, Lund og HOM 2247, Gedved Vest, tilgængelige på www.kulturarv.dk/ffreg

18. Schiørring 1991, s. 112.

19. Williams 1997, s. 96-98.

20. www.finds.org.uk.

21. Ulriksen 2011, s. 108; Pedersen 1997, s. 145.

22. Waurich 1992, s. 125.

23. Baastrup 2007; Baastrup 2013.

24. Pedersen 1999, s. 22.

25. Pedersen 1999, s. 20. 
26. Pantmann 2011, s. 76-77.

27. Sørensen 2003, s. 444.

28. Skov 2011, s. 120.

29. Kristiansen 2006.

30. Callesen in press.

31. Pagh in press.

32. Dokumentation af forskningsprojektet ligger på Horsens Museum under sagsnr. HOM 3284.

33. Iflg. beretningen blev der udlagt et retvinklet koordinatsystem med en afvigelse på ca. $7^{\circ}$ mod nordøst. Punktet 500/500 blev lagt vilkårligt, nogenlunde midt mellem de to udgravningsfelter. Målesystemet blev sikret ved hjælp af tre jernrør. Disse jernrør blev banket ned i følgende positioner: 1: i pkt. 500/689 (altså 189 m nord for pkt. 500/500) - i græsrabat ved den gamle Nørre Snede landevej nord for de udgravede felter, $25 \mathrm{~m}$ fra midten af Bisgårdsvej. 2: i pkt. 500/350 (150 m syd for pkt. 500/500) - i græsrabat ved Tamdrup Kirkevej. 3: i pkt. 561,40/500 (61,40 m øst for pkt. 500/500) - ved kirkegårdsdiget $22,5 \mathrm{~m}$ nord for den nordligste pille i gitterporten.

\section{LITTERATUR}

Baastrup, M.P. 2013: Continental and Insular imports in Viking Age Denmark. Distribution and cirkulation. Zeitschrift für Archaeologie des Mittelalters, Jahrgang 41, s. 85-208.

Baastrup, M.P. 2007: Vikingetidens og den tidlige middelalders emaljefibler fra Sydvestjylland. By, marsk og geest 19, s. 5-16.

Callesen, F. In press: Kontinuitet og forandring - status for 25 års byarkæologi i Horsens.

Christensen, J.K. 1976: Vikingetidens langhuse på: Trelleborg, Aggersborg, Fyrkat og Nonnebakken. København. Danmarks Kirker 2002: Tamdrup, Århus Amt, hæfte 52.

Gjedssø Bertelsen, L. 1994: Urnesfibler i Danmark. Aarbøger for Nordisk Oldkyndighed og Historie 1992, s. 345-370.

Graham-Campbell, J. 2013: Viking Art. London.

Hansen, J. 2015: Landsbydannelse og bebyggelsesstruktur i det 1. årtusinde - et bebyggelseshistorisk regionalstudie. Upubliseret ph.d.-afhandling, Syddansk Universitet, s. 90-91.

Hvass, S. 1980: Vorbasse - The Viking Age Settlement at Vorbasse, Central Jutland. Acta Archaeologica, vol. 50, 1979, s. 137-172.

Imer, L. 2015: Mod dæmoner og elverfolk. Skalk 2015, nr. 1, s. 9-15.

Jeppesen, J. \& H.J. Madsen 1989: Stormandsgård og kirke i Lisbjerg. Kuml 1988/89, s. 289-310.

Jeppesen, J. 2004: Stormandsgården ved Lisbjerg Kirke. Nye undersøgelser. Kuml, s. 161-180.

Jessen, M.D. 2015: Stave, stolper og Skagerrak - spørgsmål om ressourcer og arkitektur under Harald Blåtand. I: A. Pedersen og S.M. Sindbæk (red): Nordlige Verdener. Et felles hav - Skagerrak og Kattegat i vikingetiden. København, s. 188-209.

Jessen, M.D., S.W. Andersen, A. Pedersen, P. Jensen \& M.K. Holst 2011: Kongens gård i Jelling? Et nyt anlæg fra Harald Blåtands tid. Nationalmuseets Arbejdsmark, s. 60-73. 
Kristiansen, A.M. 2006: Ennerskatten - Ny viden om et gammelt fund. Nordisk Numismatisk Unions Medlemsblad 2, s. 63-72.

Lund, N. 2006: Harald Blåtands Dåb. Siden Saxo 23, 1, s. 4-10.

Nørlund, P. 1948: Trelleborg. Nordiske Fortidsminder, 4. bind, 1. hæfte. København.

Pagh, L. In press: Stålproduktion i Danmark i middelalderen. I: X. Pauli Jensen (red.): Smedens Rum.

Pantmann, P. 2011: The symbolism of keys in female graves on Zealand during the Viking Age. I: L. Boye (red.): The Iron Age on Zealand. Status and Perspectives. København, s. 75-80.

Pedersen, A. 2014: Dead Warriors in Living Memory - A Study of Weapon and Equestrian Burials in Viking-Age Denmark, AD 800-1000. Studies in Archaeology \& History Vol. 20:1 1-2. Jelling Series. Odense, s. 101-125.

Pedersen, A. 2001: Rovfugle eller duer. Fugleformede fibler fra den tidlige middelalder. Aarbøger for Nordisk Oldkyndighed og Historie 1999, s. 19-66.

Pedersen, A. 1997: Riding gear from Late Viking-age Denmark. Journal of Danish Archaeology vol. 13, 1996-97, s. 133-160.

Roesdahl, E., S.M. Sindbæk og A. Pedersen (red.) 2014: Aggersborg i Vikingetiden. Bebyggelsen og borgen. Jysk Arkæologisk Selskabs skrifter. Højbjerg.

Schiørring, O. (red.) 1991: Tamdrup. Kirke og gård. Ebeltoft.

Skov, H. 2011: Jomsborg og venderne. Aros og vikingernes verden. Moesgaard Museum. Højbjerg, s. 118-120.

Skov, H. 1994: Hustyper i vikingetid og tidlig middelalder. Udviklingen af hustyper i det gammeldanske område fra ca. 800-1200 e.Kr. Hikuin 21, s. 139-162.

Sørensen, A.B. 2003: Middelalderens fødsel - tiden 1000-1340 - huse, gårde og bebyggelser. I: L.S. Madsen \& O. Madsen (red.): Det Sønderjyske Landbrugs Historie. Jernalder, Vikingetid og Middelalder. Haderslev, s. 434-457.

Søvsø, M. 2014: Jyske stormandsgårde i ældre middelalder - primært belyst ved eksempler fra Ribe-egnen. By, marsk og geest 26, s. 19-38.

Ulriksen, J. 2006: Vester Egesborg - a coastal settlement from the Late Iron Age on Zealand. Journal of Danish Archaeology, vol. 14, s. 187-199.

Ulriksen, J. 2011: Fremmed indflydelse i vikingetid og tidlig middelalder (700-1150 e.Kr.). Historisk årbog for Roskilde Amt, s. 79-120.

Waurick, G. (Hrsg.) 1992: Das Reich der Salier 1024-1125. Katalog zur Ausstellung des Landes Rheinland-Pfalz. Sigmaringen.

Williams, D. 1997: Late Saxon Stirrup-Strap Mounts: A Classification and Catalogue. York. 


\section{Tamdrup \\ Royal residence and memorial church in a new light}

Tamdrup has been shrouded in a degree of mystery in recent times. The solitary church located on a moraine hill west of Horsens is visible from afar and has attracted attention for centuries. On the face of it, it resembles an ordinary parish church, but on closer examination it is found to be unusually large, and on entering one discovers that hidden beneath one roof is a three-aisled construction, which originally was a Romanesque basilica.

Why was such a large church built in this particular place? What were the prevailing circumstances in the Early Middle Ages when the foundation stone was laid?

The mystery of Tamdrup has been addressed and discussed before. In the 1980s and 1990s, archaeological excavations were carried out which revealed traces of a magnate's farm or a royal residence from the Late Viking Age or Early Middle Ages located on the field to the west of the church (fig. 4), and in 1991, the book Tamdrup - Kirke og gård was published.

Now, by way of metal-detector finds, new information has been added. These new finds provide several answers, but also give rise to several new questions and problems. In recent years, a considerable number of metal finds recovered by metal detector at Tamdrup have been submitted to Horsens Museum. Since 2012, 207 artefacts have been recorded, primarily coins, brooches, weights and fittings from such as harness, dating from the Late Viking Age and Early Middle Ages. Further to these, a coin hoard dating from the time of Svein Estridson was excavated in 2013.

The museum has processed the submitted finds, which have been recorded and passed on for treasure trove evaluation. As resources were not available for a more detailed assessment of the artefacts, in 2014 the museum formulated a research project that received funding from the Danish Agency for Culture, enabling the finds to be examined in greater depth.

The aim of the research project was to study the metal-detector finds and the excavation findings, partly through an analysis of the total finds assemblage, partly by digitalisation of the earlier excavation plans so these could be compared with each other and with the new excavation data. This was intended to lead on to a new analysis, new interpretations and a new, overall evaluation of Tamdrup's function, role and significance in the Late Viking Age and Early Middle Ages.

\section{Old excavations - new interpretations}

In 1983, on the eastern part of the field, a trial excavation trench was laid out running north-south (d). This resulted in two trenches $(a, b)$ and a further three trial trenches being opened up in 1984 (fig. 6). In the northern trench, a longhouse, a fence and a pit-house were discovered (fig. 8). The interpretation of the longhouse (fig. 4) still stands, in so far as we are dealing with a longhouse with curved walls. The western end of the house appears unequivocal, but there could be some doubt about its eastern end. An alternative interpretation is a 17.5 $\mathrm{m}$ long building (fig. 8), from which the easternmost set of roof-bearing posts are excluded. Instead, another posthole is included as the northernmost post in the gable to the east. This gives a house with 
regularly curved walls, though with the eastern gable $(4.3 \mathrm{~m})$ narrower than the western $(5.3 \mathrm{~m})$.

North of the trench (a) containing the longhouse, a trial trench (c) was also laid out, revealing a number of features. Similarly, there were also several features in the northern part of the middle trial trench (e). A pit in trial trench $\mathrm{c}$ was found to contain both a fragment of a bit branch and a bronze key. There was neither time nor resources to permit the excavation of these areas in 1984, but it seems very likely that there are traces of one or more houses here (fig. 9). Here we have a potential site for a possible main dwelling house or hall.

In August 1990, on the basis of an evaluation, an excavation trench (h) was opened up to the west of the 1984 excavation (fig. 7). Here, traces were found of two buildings, which lay parallel to each other, oriented east-west. These were interpreted as small auxiliary buildings associated with the same magnate's farm as the longhouse found in the 1984 excavation. The northern building was $4 \mathrm{~m}$ wide and the southern building was 5.5 $\mathrm{m}$. Both buildings were considered to be c. $7 \mathrm{~m}$ long and with an open eastern gable. The southern building had one set of internal roof-bearing posts.

The excavation of the two buildings in 1990 represented the art of the possible, as no great resources were available. Aerial photos from the time show that the trial trench from the evaluation was back-filled when the excavation was completed. Today, we have a comprehensive understanding of the trial trenches and excavation trenches thanks to the digitalised plans. Here, it becomes apparent that some postholes recorded during the evaluation belong to the southernmost of the two buildings, but these were unfortunately not relocated during the actual excavation. As these postholes, accordingly, did not form part of the interpretation, it was assumed that the building was $7 \mathrm{~m}$ in length (fig. 10). When these postholes from the evaluation are included, a ground plan emerges that can be interpreted as the remains of a Trelleborg house (fig. 11). The original $7 \mathrm{~m}$ long building constitutes the western end of this characteristic house, while the remainder of the south wall was found in the trial trench. Part of the north wall is apparently missing, but the rest of the building appears so convincing that the missing postholes must be attributed to poor conditions for preservation and observation. The northeastern part of the house has not been uncovered, which means that it is not possible to say with certainty whether the house was 19 or $25 \mathrm{~m}$ in length, minus its buttress posts.

On the basis of the excavations undertaken in 1984 and 1990, it was assumed that the site represented a magnate's farm from the Late Viking Age. It was presumed that the excavated buildings stood furthest to the north on the toft and that the farm's main dwelling - in the bestcase scenario the royal residence - should be sought in the area to the south between the excavated buildings. Six northsouth-oriented trial trenches were therefore laid out in this area (figs. 6, 7 and 13 - trial trenches o, p, q, r, s and t). The results were, according to the excavation report, disappointing: No trace was found of Harold Bluetooth's hall. It was concluded that there were no structures and features that could be linked together to give a larger entity such as the presumed magnate's farm.

After digitalisation of the excavation plans from 1991, we now have an overview of the trial trenches to a degree that was not possible previously (fig. 13). It is clear that there is a remarkable concen- 
tration of structures in the central and northern parts of the two middle trial trenches (q, r) and in part also in the second (p) and fourth (s) trial trenches from the west, as well as in the northern parts of the two easternmost trial trenches $(s, t)$. An actual archaeological excavation would definitely be recommended here if a corresponding intensity of structures were to be encountered in an evaluation today (anno 2016).

Now that all the plans have been digitalised, it is obvious to look at the trial trenches from 1990 and 1991 together. Although some account has to be taken of uncertainties in the digitalisation, this nevertheless confirms the picture of a high density of structures, especially in the middle of the 1991 trial trenches. The collective interpretation from the 1990 and 1991 investigations is that there are strong indications of settlement in the area of the middle 1991 trial trenches. It is also definitely a possibility that these represent the remains of a longhouse, which could constitute the main dwelling house. It can therefore be concluded that it is apparently possible to confirm the interpretation of the site as a potential royal residence, even though this is still subject to some uncertainty in the absence of new excavations. The archaeologists were disappointed following the evaluation undertaken in 1991, but the overview which modern technology is able to provide means that the interpretation is now rather more encouraging. There are strong indications of the presence of a royal residence.

\section{Finds}

The perception of the area by Tamdrup church gained a completely new dimension when the first metal finds recovered by metal detector arrived at Horsens Museum in the autumn of 2011. With time, as the finds were submitted, considerations of the significance and function of the locality in the Late Viking Age and Early Middle Ages were subjected to revision. The interpretation as a magnate's farm was, of course, common knowledge, but at Horsens Museum there was an awareness that this interpretation was in some doubt following the results of the 1991 investigations. The many new finds removed any trace of this doubt while, at the same time, giving cause to attribute yet further functions to the site. Was it also a trading place or a central place in conjunction with the farm? And was it active earlier than previously assumed?

The 207 metal finds comprise 52 coins (whole, hack and fragments), 34 fittings (harness, belt fittings etc.), 28 brooches (enamelled disc brooches, Urnes fibulas and bird brooches), 21 weights, 15 pieces of silver (bars, hack and casting dead heads), 12 figures (pendants, small horses), nine distaff whorls, eight bronze keys, four lead amulets, three bronze bars, two fragments of folding scales and a number of other artefacts, the most spectacular of which included a gold ring and a bronze seal ring. In dating terms, most of the finds can be assigned to the Late Viking Age and Early Middle Ages.

The largest artefact group consists of the coins, of which 52 have been found either whole or as fragments. To these can be added the coin hoard, which was excavated in 2013 (fig. 12) and which primarily consists of coins minted under Svein Estridson. The other, non-hoard coins comprise: 13 Svein Estridson (figs. 15, 16), five Otto-Adelheid, five Arabic dirhams, three Sancta Colonia, one Canute the Great, one Edward the Confessor, one Theodorich II, one Heinrich II, one Rand pfennig, one Roman denarius (with drilled hole) and nine unidentified silver coins, of which some appear however to be German and others Danish/AngloSaxon. Most of the single coins date from the late 10th and early 11th centuries. 
The next-largest category of finds from Tamdrup are the fittings, which comprise 34 items. This category does, however, cover a broad diversity of finds, of which the dominant types are belt/strap fittings of various kinds and fittings associated with horse harness (figs. 17-24). In total, ten fittings have been found by metal detector that are thought to belong to harness. In addition to these is a single example from the excavation in 1984. The majority of these fittings are interpreted as parts of curb bits, headgear and stirrups.

One particularly expressive figure was found at Tamdrup: a strap fitting from a stirrup, formed in a very characteristic way and depicting the face of a Viking (fig. 20). The fitting has been fixed on the stirrup strap at the point where the sides meet. Individual stirrup strap fittings are known by the hundred from England and are considered stylistically to be AngloScandinavian. The fitting from Tamdrup is dated to the 11th century and is an example of a Williams' Class B, Type 4, East Anglian type face mount.

A special category of artefacts is represented by the brooches/fibulas, and enamel brooches are most conspicuous among the finds from Tamdrup. Of the total of 28 examples, 11 are enamel brooches. The most unusual is a large enamel disc brooch of a type that probably has not been found in Denmark previously (fig. 24). Its size alone $(5.1 \mathrm{~cm}$ in diameter) is unusual. The centre of the brooch is raised relative to the rim and furnished with a pattern of apparently detached figures. On the rim are some alternating sail-shaped triangles on a base line which forms four crown-like motifs and defines a cruciform shape. Between the crowns are suggestions of small pits that probably were filled with enamel.

Parallels to this type are found in central Europe, and the one that approaches closest stylistically is a brooch from Komjatice in western Slovakia, found in a grave (fig. 25). This brooch has a more or less identical crown motif, and even though the other elements are not quite the same, the similarity is striking. It is dated to the second half of the 10th century and the first half of the 11th century.

The other enamel brooches are wellknown types of small Carolingian and Ottonian brooches. There are four circular enamel cross-motif brooches (fig. 26a), two stellate disc brooches with central casing (fig. 26b), one stepped brooch with a cruciform motif, one cruciform fibula with five square casings and two discshaped brooches.

In addition to the enamel brooches there are ten examples that can definitely be identified as animal brooches. Nine of these are of bronze, while one is of silver. The motifs are birds or dragons in Nordic animal styles from the Late Viking Age, Urnes and Ringerike styles, and simpler, more naturalistic forms of bird fibulas from the Late Viking Age and Early Middle Ages. Accordingly, the date for all the animal brooches is the 11th and 12th centuries.

A total of 21 weights of various shapes and forms have been found at Tamdrup: spherical, bipolar spherical, disc-shaped, conical, square and facetted in various ways. Rather more than half are of lead, with the remainder being of bronze, including a couple of examples with an iron core and a mantle of bronze (so-called ørtug weights), where the iron has exploded out through the bronze mantle. One of the bipolar spheres (fig. 28) has ornamentation in the form of small pits on its base. Weights are primarily associated with trade, where it was important to be able to weigh an agreed amount of silver. Weights were, however, also used in the metal workshops, where it was crucial to be able to weigh a particular amount of metal 
for a specific cast in order to achieve the correct proportions between the different metals in an alloy.

Eight bronze keys have been found, all dated broadly to the Viking Age (fig. 29). Most are fragmentarily preserved pieces of relatively small keys of a very simple type that must be seen as being for caskets or small chests. Keys became relatively widespread during the course of the Viking Age. Many were of iron and a good number of bronze. Nevertheless, the number of keys found at Tamdrup is impressive.

A further group of artefacts that will be briefly mentioned are the distaff whorls. This is an artefact group which appears in many places and which was exceptionally common in the Viking Age. In archaeological excavations, examples are often found in fired clay, while metal distaff whorls - most commonly of lead - are found in particular by metal detector. Nine distaff whorls have been found at Tamdrup, all of lead.

The finest and absolutely most prestigious artefact is a gold ring, which was found c. $60 \mathrm{~m}$ southwest of house 1 . The ring consists of a $2 \mathrm{~mm}$ wide, very thin gold band, while the fittings comprise a central casing surrounded by originally eight small circular casings. In the middle sits a red stone, presumably a garnet, mounted in five rings. In a circle around the stone are the original eight small, circular mounts, of which six are preserved. The mounts, from which the stones are missing, alternate with three small gold spheres. The edges of the mounts have fine cable ornamentation. The dating is rather uncertain and is therefore not ascribed great diagnostic value. In the treasure trove description, the ring is dated to the Late Middle Ages/Renaissance, but it could presumably also date from the Early Middle Ages as it has features reminiscent of the magnificent brooch found at Østergård, which is dated to 1050 .
Two other spectacular artefacts were found in the form of some small fourlegged animals, probably horses, cast in bronze. These figures are known from the Slav area and have presumably had a pre-Christian, symbolic function. Common to both of them are an elongated body, long neck and very short legs.

Finally, mention should be made of four lead amulets. These are of a type where, on a long strip of lead, a text has been written in runes or Latin characters. Typically, these are Christian invocations intended to protect the wearer. The lead amulets are folded together and therefore do not take up much space. They are dated to the Middle Ages (1100-1400) and will therefore not be dealt with in further detail here.

\section{What the artefacts tell us}

What do the artefacts tell us? They help to provide a dating frame for the site, they tell us something about what has taken place there, they give an indication of which social classes/strata were represented, and, finally, they give us an insight into which foreign contacts could have existed, which influences people were under and which networks they were part of.

Most of the artefacts date from the period 900-1000, and this is also the dating frame for the site as a whole. There is a slight tendency for the 10th century finds to be more evenly distributed across the site than those from the 11th century, which tend to be concentrated in the eastern part.

A number of the finds are associated with tangible activities, for example the weights and, especially, the distaff whorls. Others also had practical functions but are, at the same time, associated with the upper echelons of society. Of the material from Tamdrup, the latter include the harness fittings and the keys, while the many brooches/fibulas and pendants also belong 
to artefact groups to which people from the higher strata of society had access.

Some of the harness fittings and brooches suggest links with England. The stirrup-strap fitting and the cruciform strap fitting in Anglo-Scandinavian style have clear parallels in the English archaeological record. The coins, on the other hand, point towards Germany. There are a number of German coins from the end of the 10th century and the beginning of the 11th century, but the occurrence of Otto-Adelheid pennies and other German coins is not necessarily an indication of a direct German connection. From the second half of the 11th century, Svein Estridson coins dominate, but they are primarily Danish. Other artefacts that indicate contacts with western Europe are the enamelled brooches in CarolingianOttonian style.

A number of objects suggest some degree of trade. Here again, it is the coins and the hack silver, and also the relatively large number of lead weights, that must be considered as relatively reliable indicators of trade, at least when their number is taken into consideration.

In the light of the metal-detector finds it can, in conclusion, be stated that this was a locality inhabited by people of middle to high status. Many objects are foreign or show foreign inspiration and suggest therefore that Tamdrup was part of an international network. The artefacts support the interpretation of Tamdrup as a magnate's farm and a royal residence.

\section{Conclusion}

Tamdrup was located high up in the landscape, withdrawn from the coast, but nevertheless with quick and easy access to Horsens Fjord. Tamdrup could be approached from the fjord via Nørrestrand and the river Hansted $\AA$ on a northern route, or by the river Bygholm $\AA$ on a southern route (fig. 33). A withdrawn location was not atypical in the Viking Age and the Early Middle Ages. At that time there were also sites directly on the coast and at the heads of fjords, where early urbanisation materialised through the establishment of the first market towns, while the king's residences had apparently to be located in places rather less accessible by boat and ship. As withdrawn but central, regional hubs and markers between land and sea.

One must imagine that Tamdrup had a high status in the 10th and 11th centuries, when the king had a residence and a wooden church there. A place of great importance, culminating in the construction of a Romanesque basilica to commemorate the Christianisation of Denmark. Tamdrup appears to have lost its significance for the monarchy shortly after the stone church was completed, which could fit with King Niels, as the last of Svein Estridson's sons, being killed in 1134, and another branch of the royal family taking over power. At the same time as Tamdrup lost its importance, Horsens flourished as a town and became of such great importance for the Crown that both Svein Grathe and Valdemar the Great had coins minted there. Tamdrup must have been a central element of the local topography in the Viking Age, when Horsens functioned as a landing place, perhaps with seasonal trading. In the long term, Horsens came out strongest, but it must be assumed that Tamdrup had the highest status between AD 900 and 1100 .

Lars Pagh

Horsens Museum 